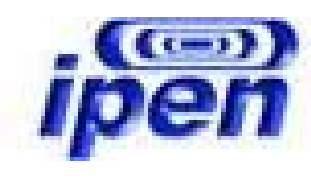

Autarquia Associada à Universidade de São Paulo

\title{
CARACTERIZAÇÃO DO RESÍDUO SÓLIDO FORMADO EM MOTOR AUTOMOTIVO À GASOLINA POR MEIO DE TÉCNICAS ANALÍTICAS
}

\author{
Djalma de Mello
}

\author{
Dissertação apresentada como parte \\ dos requisitos para obtenção do \\ Grau de mestre na Área de \\ Tecnologia Nuclear-Materiais \\ Orientador: \\ Dr. Waldemar Alfredo Monteiro
}

São Paulo

2008 
Instituto de Pesquisas Energéticas e Nucleares

Autarquia Associada à Universidade de São Paulo

\title{
CARACTERIZAÇÃO DO RESÍDUO SÓLIDO FORMADO EM MOTOR AUTOMOTIVO À GASOLINA POR MEIO DE TÉCNICAS ANALÍTICAS
}

\author{
Djalma de Mello
}

Dissertação apresentada como parte dos requisitos para obtenção do Grau de mestre na Área de Tecnologia NuclearMateriais

Orientador:

Dr. Waldemar Alfredo Monteiro

São Paulo

2008 
Aos meus filhos, Danilo, Fernanda e Luís Gustavo e netos Renan, Livia e Letícia por simplesmente existirem em minha vida. 
À Márcia que traz sentido a minha vida... 
Ao Prof. Dr. Waldemar Alfredo Monteiro por todo ensinamento, orientação, incentivo, dedicação e apoio para realização desta dissertação. 


\section{AGRADECIMENTOS}

À General Motors do Brasil por todo apoio e contribuição e pela utilização dos laboratórios para os ensaios realizados.

A todos da Faculdade de São Bernardo do Campo, em especial a Direção por incentivarem a realização deste trabalho.

Aos Funcionários e Professores do IPEN pela colaboração e aprendizado. 


\title{
CARACTERIZAÇÃO DO RESÍDUO SÓLIDO FORMADO EM MOTOR AUTOMOTIVO À GASOLINA POR MEIO DE TÉCNICAS ANALÍTICAS
}

\section{Djalma de Mello}

\begin{abstract}
RESUMO
As principais causas da formação do resíduo sólido no motor são: alta temperatura que leva a oxidação do óleo; combustível de má qualidade; diluição do óleo por combustível e gases de combustão; óleo de baixa qualidade (recuperado) e a não troca do óleo no motor, apenas adição para acertar o nível. O resíduo é formado pela reação de oxidação e o catalisador deste processo pode ser o calor (acima de $50-60^{\circ} \mathrm{C}$ ). A cada $10^{\circ} \mathrm{C}$ de aumento na temperatura, dobrase a oxidação resultando na polimerização do óleo (borra). Assim, torna-se importante caracterizar o resíduo para propor meios de minimização ou eliminação deste. Neste trabalho são utilizadas a espectrometria de emissão atômica que caracteriza a presença dos metais, a microscopia eletrônica de varredura com microanálise que caracteriza a microestrutura e identifica presença de elementos químicos no resíduo sólido e a espectrometria de absorção no infravermelho para identificar os grupos funcionais, buscando associar a composição do resíduo com os possíveis fatores que causam sua formação.
\end{abstract}




\title{
CHARACTERIZATION OF SOLID DEPOSIT FORMED IN AUTOMOTIVE GASOLINE ENGINE BY THE ANALYTICAL TECHNIQUES
}

\section{Djalma de Mello}

\begin{abstract}
The main issues for solid deposit in engine are: high temperature that causes oil oxidation, bad quality fuel, dilution of fuel and combustion gases, low engine oil quality (recouped) and the engine oil not changed, but only completed up to the level required. The deposit is formed by a reaction to oxidation and heat (above 50$60^{\circ} \mathrm{C}$ ) can catalyze the process. At every $10^{\circ} \mathrm{C}$ of increase in temperature, oxidation will be doubled, that will result in oil polymerization. Therefore, it's important to defines the deposit so as to minimize or eliminate it. It is known that by means of infrared absorption spectrometry functional groups can be identified. It's used atomic emission spectrometry that defines the metals content and electronic microscopic EDS, with microanalysis, that define the microstructure and identify the chemical elements in solid deposits.
\end{abstract}




\section{SUMÁRIO}

1. ASPECTOS GERAIS DO PETRÓLEO 09

1.1 ORIGEM DO PETRÓLEO 10

1.2 HISTÓRICO DO PETRÓLEO 11

1.3 COMPOSIÇÃO DO PETRÓLEO 12

1.4 INDÚSTRIA DO PETRÓLEO 20

1.5 REFINO DO PETRÓLEO 22

1.5.1 Processos de Separação 23

1.5.2 Processos de Conversão 23

1.5.3 Processos de Tratamento 24

1.5.4 Processos Auxiliares 25

2. CONSIDERAÇÕES GERAIS DA GASOLINA 28

2.1. COMPOSIÇÃO QUÍMICA DA GASOLINA 29

2.2 DESTILAÇAึ̄O 32

2.3 RECUPERAÇÃO DA GASOLINA NATURAL 33

2.4 CRAQUEAMENTO 33

2.5 HIDROCRAQUEAMENTO 34

2.6 REFORMA 34

2.7 ALQUILAÇÃO OU ALCOILAÇÃO 35

2.8 POLIMERIZAÇÃO 35

2.9 ISOMERIZAÇÃ̃O 36

$\begin{array}{ll}2.10 \text { OCTANAGEM } & 37\end{array}$

2.11 TIPOS DE GASOLINA 38

2.12 ADULTERAÇÃO DA GASOLINA 42

2.13 ESPECIFICAÇÕES DA GASOLINA AUTOMOTIVA 45

2.13.1 Cor e aspecto 48

2.13.2 Misturas com álcool $\quad 48$

2.13.3 Destilação 50

2.13.4 Índice de octano 53

2.13.5 Pressão de vapor 58

2.13.6 Aditivos $\quad 59$

2.13.7 Resíduo no motor 64

3. MATERIAIS E MÉTODOS 65

3.1 MATERIAIS E MÉTODOS PARA CARACTERIZAÇÃO 65

3.1.1 Espectrometria de Absorção no Infravermelho $\quad 66$

3.1.2 Espectrometria de Emissão Atômica 67

3.1.3 Microscopia Eletrônica de Varredura 68 
4. DESENVOLVIMENTO EXPERIMENTAL 71

4.1 PREPARO DA AMOSTRA PARA ANÁLISE POR 71 MICROSCOPIA ELETRÔNICA DE VARREDURA

4.2 PREPARO DA AMOSTRA PARA ANÁLISE POR

72 ESPECTROFOTOMERIA DE EMISSÃO POR PLASMA ACOPLADO INDUTIVAMENTE

4.3 PREPARO DA AMOSTRA PARA ANÁLISE POR

72 ESPECTROFOTOMETRIA DE ABOSRÇÃO NO INFRAVERMELHO COM TRANSFORMADA DE FOURIER

4.3 REAGENTES E QUIPAMENTOS UTILIZADOS 72

5. RESULTADOS E DISCUSSÕES

6. CONCLUSÕES 


\section{ASPECTOS GERAIS DO PETRÓLEO}

Petróleo é uma palavra originada do Latim Petra (pedra) + Oleum (óleo). O petróleo bruto é uma complexa mistura de compostos orgânicos e inorgânicos em que predominam os hidrocarbonetos, desde alcanos mais simples até os aromáticos mais complexos.

De acordo com a ASTM - American Society for Testing and Materials - o petróleo é uma mistura de ocorrência natural, consistindo predominantemente de hidrocarbonetos, derivados orgânicos sulfurados, nitrogenados e/ou oxigenados (chamados genericamente de compostos NOS) e metais, principalmente níquel e vanádio, os quais têm pouca aplicação em seu estado natural (AMERICAN OIL CHEMISTS SOCIETY, 1988).

O petróleo é encontrado em muitos lugares da crosta terrestre e em grandes quantidades, e desse modo o seu processo de formação deve ter sido espontâneo. É uma substância oleosa, inflamável, com odor característico, menos denso que a água (em geral) e com coloração que pode variar desde o incolor ou castanho claro até o preto, passando por verde e marrom.

Encontrada nas rochas de bacias sedimentares e originada da decomposição da matéria orgânica depositada no fundo dos mares e lagos que sofreu transformações químicas pela ação de temperatura, pressão, pouca oxigenação e bactérias.

Tais transformações prosseguem em maior ou menor grau até o momento da descoberta da jazida e extração do petróleo nela contido. Dessa forma, é virtualmente impossível a obtenção de amostras de petróleo com a mesma composição química, até mesmo em um mesmo campo produtor. A Figura 1 a seguir indica o processo de formação do petróleo. 
Quase todos os petróleos conhecidos mostram atividade ótica, sendo a maioria dextrógira. Consequentemente, ele deve ser oriundo de organismos vivos, pois apenas estes são oticamente ativos (GUIBET, 1999).

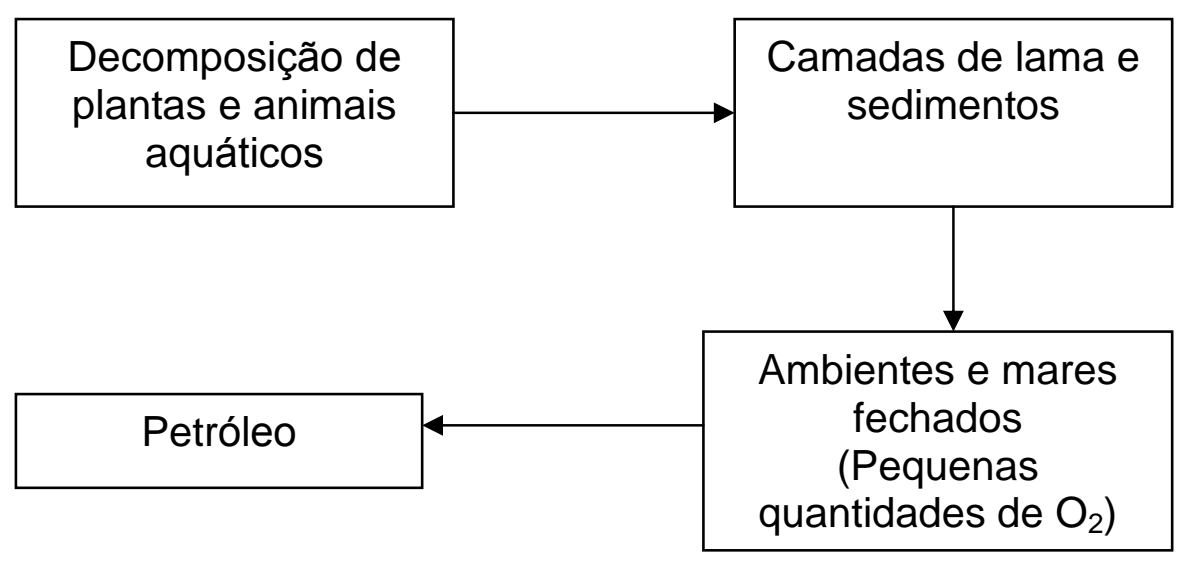

Figura 1 - Processo de formação de petróleo.

No petróleo bruto estão presentes compostos que se decompõem acima de $200^{\circ} \mathrm{C}$, dos quais a porfirina é o mais conhecido. Isto leva a admitir que ao longo de seu processo de formação, a temperatura não tenha sido superior a este valor (GUIBET, 1999).

\subsection{ORIGEM DO PETRÓLEO}

Com a ação da temperatura e pressão e ainda com a ação de bactérias ao longo do tempo, a massa de detritos se transforma em gases e compostos solúveis em água e em material sólido remanescente, que continua a sofrer a ação das bactérias até passar para um estado semi-sólido (pastoso). 
Através de um processo de craqueamento catalisado por minerais contidos na rocha-matriz, este material sólido passa para o estado líquido.

Esta substância líquida separa-se da água do mar que resta nestes sedimentos, e flutua em função de sua menor densidade.

Com a pressão das camadas da rocha-matriz, o óleo flui no sentido da pressão mais baixa através dos poros da rocha, até encontrar uma posição de equilíbrio em que a pressão por ele exercida seja igual à da água também presente nos poros.

O petróleo se esconde nestes poros e ainda pode sofrer pequenas variações em sua composição através de processos físicos, até sua descoberta na fase exploratória (GUIBET, 1999).

\subsection{HISTÓRICO DO PETRÓLEO}

Não se sabe quando a atenção do homem foi despertada, mas o fato é que o petróleo, assim como o asfalto e o betume, eram conhecidos desde os primórdios das civilizações.

Nabucodonosor, por exemplo, usou o betume como material de liga nas construções dos célebres Jardins Suspensos da Babilônia. Betume foi também utilizado para impermeabilizar a Arca de Noé. Os egípcios o usaram pra embalsamar os mortos e na construção de pirâmides, enquanto gregos e romanos o empregaram com fins bélicos.

Só no século XVIII, porém, é que o petróleo começou a ser usado comercialmente, na indústria farmacêutica e na iluminação. Até a metade do século XIX, não havia ainda a idéia, ousada para a época, de perfuração de poços petrolíferos. 
As primeiras tentativas aconteceram nos Estados Unidos, com Edwin L. Drake, que enfrentou diversas dificuldades técnicas. Após meses de perfuração, Drake encontra o petróleo, a 27 de agosto de 1859.

Após cinco anos, achavam-se constituídas, nos Estados Unidos, nada menos que 543 companhias entregues ao novo e rendoso ramo de atividade de exploração de petróleo.

$\mathrm{Na}$ Europa, paralelamente à fase de Drake, desenvolveu-se uma reduzida indústria de petróleo, que sofreu a dura competição do carvão, linhita, turfa e alcatrão.

Naquela época, as zonas urbanas usavam velas de cera, lâmpadas de óleo de baleia e iluminação por gás e carvão. Enquanto isso, a população rural não dispunha de iluminação noturna, despertando com o sol e dormindo ao escurecer (GUIBET, 1999).

\subsection{COMPOSIÇÃO DO PETRÓLEO}

O petróleo cru tem uma composição centesimal com pouca variação, à base de hidrocarbonetos de séries homólogas. As diferenças em suas propriedades físicas são explicadas pela quantidade relativa de cada série e de cada componente individual.

Os hidrocarbonetos formam cerca de $80 \%$ de sua composição. Complexos organometálicos e sais de ácidos orgânicos respondem pela constituição em elementos orgânicos. Gás sulfídrico $\left(\mathrm{H}_{2} \mathrm{~S}\right)$ e enxofre elementar respondem pela maior parte de sua constituição em elementos inorgânicos. Geralmente, gases e água também acompanham o petróleo bruto.

Os compostos que não são classificados como hidrocarbonetos concentram-se nas frações mais pesadas do petróleo. 
A composição elementar média do petróleo é estabelecida conforme indicado na Tabela 1.

Tabela 1 - Composição elementar média do petróleo (GUIBET, 1999).

\begin{tabular}{cc}
\hline \hline Elemento & Percentagem em Peso (\%) \\
\hline Carbono & $83,9-86,9$ \\
Hidrogênio & $11,4-14,0$ \\
Enxofre & $0,06-9,00$ \\
Nitrogênio & $0,11-1,70$ \\
Oxigênio & 0,50 \\
Metais (Fe, Ni, V, entre outros) & 0,30 \\
\hline
\end{tabular}

Os hidrocarbonetos podem ocorrer no petróleo desde o metano $\left(\mathrm{CH}_{4}\right)$ até compostos com mais de 60 átomos de carbono.

Os átomos de carbono podem estar conectados através de ligações simples, duplas ou triplas, e os arranjos moleculares são os mais diversos, abrangendo estruturas lineares, ramificadas ou cíclicas, saturadas ou insaturadas, alifáticas ou aromáticas.

Os alcanos têm fórmula química geral $\mathrm{C}_{n} \mathrm{H}_{2 n+2}$ e são conhecidos na indústria do petróleo como parafinas. São os principais constituintes do petróleo leve, encontrando-se nas frações de menor densidade. Quanto maior o número de átomos de carbono na cadeia, maior será a temperatura de ebulição.

$$
\begin{aligned}
& \mathrm{C}_{1}-\mathrm{C}_{4} \text { - hidrocarbonetos gasosos. } \\
& \mathrm{C}_{5}-\mathrm{C}_{17} \text { - hidrocarbonetos líquidos. } \\
& \mathrm{C}_{18} \text { - hidrocarbonetos sólidos. }
\end{aligned}
$$


As olefinas são hidrocarbonetos cujas ligações entre carbonos são realizadas através de ligações duplas em cadeias abertas, podendo ser normais ou ramificadas (fórmula química geral $\mathrm{C}_{n} \mathrm{H}_{2 n}$ ). Não são encontradas no petróleo bruto; sua origem vem de processos fisico-químicos realizados durante o refino, como o craqueamento. Possuem características e propriedades diferentes dos hidrocarbonetos saturados.

Os hidrocarbonetos acetilênicos são compostos que possuem ligação tripla (Fórmula química geral $\mathrm{C}_{\mathrm{n}} \mathrm{H}_{2 \mathrm{n}-2}$ ).

Os ciclanos, de fórmula geral $\mathrm{C}_{n} \mathrm{H}_{2 n}$, contêm um ou mais anéis saturados e são conhecidos na indústria do petróleo como compostos naftênicos, por se concentrarem na fração de petróleo denominada nafta. São classificados como cicloparafinas, de cadeia do tipo fechada e saturada, podendo também conter ramificações. As estruturas naftênicas que predominam no petróleo são os derivados do ciclopentano e do ciclohexano.

Em vários tipos de petróleo, podem-se encontrar compostos naftênicos com 1, 2 ou 3 ramificações parafínicas como constituintes principais. Em certos casos, podem-se ainda encontrar compostos naftênicos formados por dois ou mais anéis conjugados ou isolados.

Os cortes de petróleo referentes à nafta apresentam uma pequena proporção de compostos aromáticos de baia massa molecular (benzeno, tolueno e xileno).

Os derivados intermediários (querosene e gasóleo) contêm compostos aromáticos com ramificações na forma de cadeias parafínicas substituintes.

Podem ser encontrados ainda compostos mistos, que apresentam núcleos aromáticos e naftênicos.

Assim, os tipos de hidrocarbonetos presentes ou originários do petróleo são agrupados as seguinte forma: 


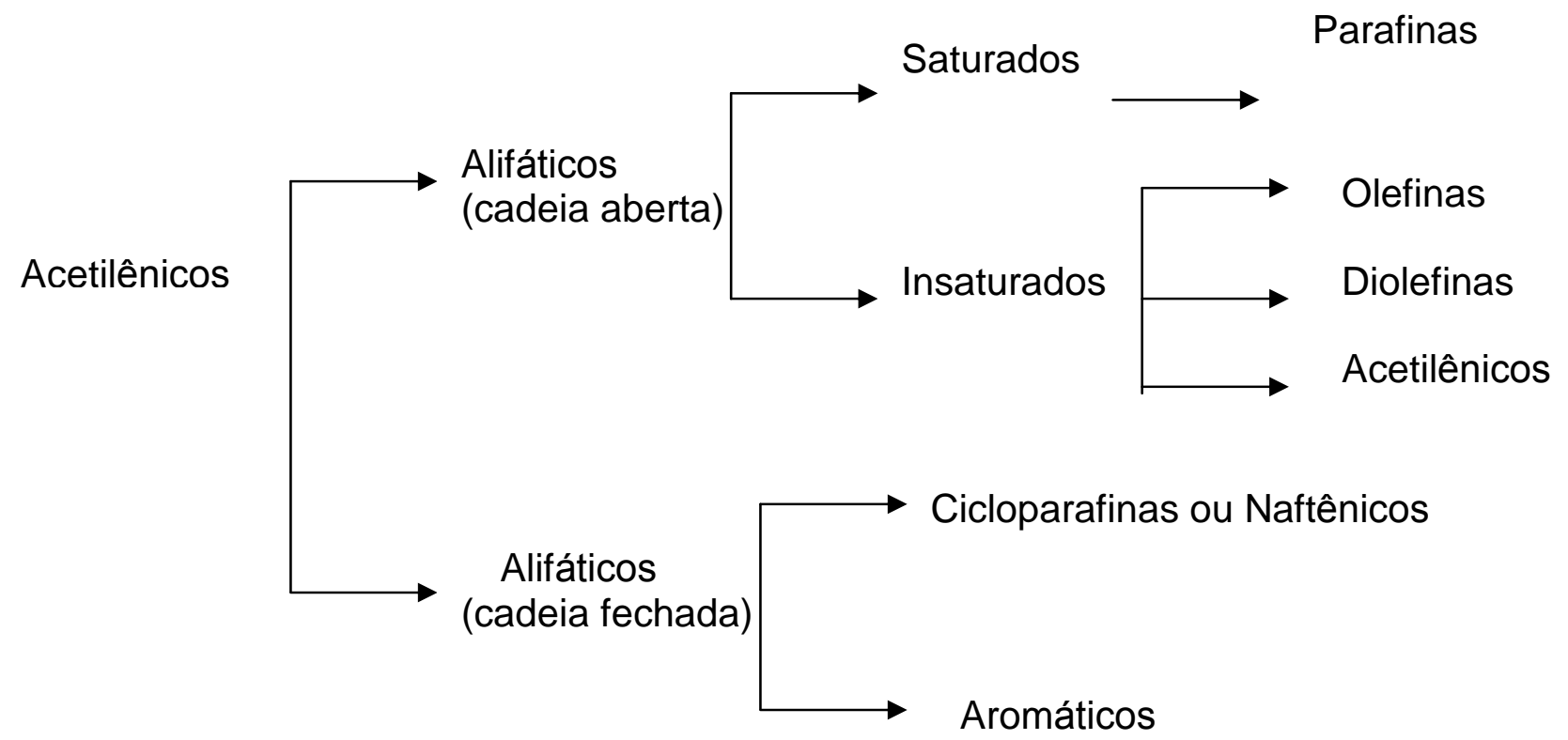

O Quadro 1, a seguir resume as principais propriedades fisico-químicas de alguns hidrocarbonetos presentes no petróleo. Observe-se, em especial, a larga faixa de valores de seus pontos de ebulição.

Todos os tipos de petróleo contêm efetivamente os mesmos hidrocarbonetos, porém em diferentes quantidades.

A quantidade relativa de cada classe do hidrocarboneto presente é muito variável de petróleo para petróleo. Como conseqüência, as características dos tipos de petróleo serão diferentes, de acordo com essas quantidades.

No entanto, a quantidade relativa dos compostos individuais dentro de uma mesma classe de hidrocarbonetos apresenta pouca variação, sendo aproximadamente da mesma ordem de grandeza para diferentes tipos de petróleo.

Petróleo bruto $=$ hidrocarbonetos + contaminantes . 
Nas refinarias, a separação destes componentes permite a geração de diversos produtos (mais de 350 tipos) com características distintas, o que traz grande utilidade (CAMPOS, 1990).

Quadro 1 - Principais propriedades fisco-químicas de alguns hidrocarbonetos (CAMPOS, 1990).

\begin{tabular}{|c|c|c|c|c|}
\hline \multicolumn{5}{|c|}{$\begin{array}{c}\text { Hidrocarbonetos Parafínicos } \\
\text { Quadro Demonstrativo das Principais Características }\end{array}$} \\
\hline Hidrocarboneto & Fórmula & $\begin{array}{l}\text { Ponto de } \\
\text { Fusão }\left({ }^{\circ} \mathrm{C}\right)\end{array}$ & $\begin{array}{l}\text { Ponto de } \\
\text { Ebulição } \\
\left({ }^{\circ} \mathrm{C}\right)\end{array}$ & $\begin{array}{c}\text { Massa Específica } \\
\text { como Líquido } \\
20^{\circ} \mathrm{C} / 4^{\circ} \mathrm{C}\end{array}$ \\
\hline Metano & $\mathrm{CH}_{4}$ & $-182,5$ & $-161,7$ & $0,2600\left(15^{\circ} \mathrm{C} / 4^{\circ} \mathrm{C}\right)$ \\
\hline Etano & $\mathrm{C}_{2} \mathrm{H}_{6}$ & $-183,3$ & $-88,6$ & 0,3400 \\
\hline Propano & $\mathrm{C}_{3} \mathrm{H}_{8}$ & $-187,7$ & $-42,0$ & 0,5000 \\
\hline Butano & $\mathrm{C}_{4} \mathrm{H}_{10}$ & $-138,4$ & $-0,5$ & 0,5788 \\
\hline Pentano & $\mathrm{C}_{5} \mathrm{H}_{12}$ & $-129,7$ & 36,1 & 0,6262 \\
\hline Hexano & $\mathrm{C}_{6} \mathrm{H}_{14}$ & $-95,3$ & 68,7 & 0,6594 \\
\hline Heptano & $\mathrm{C}_{7} \mathrm{H}_{16}$ & $-90,5$ & 98,4 & 0,6837 \\
\hline Octano & $\mathrm{C}_{8} \mathrm{H}_{18}$ & $-56,8$ & 125,6 & 0,7025 \\
\hline Nonano & $\mathrm{C}_{9} \mathrm{H}_{20}$ & $-53,7$ & 150,7 & 0,7176 \\
\hline Decano & $\mathrm{C}_{10} \mathrm{H}_{22}$ & $-29,7$ & 174,0 & 0,7300 \\
\hline Undecano & $\mathrm{C}_{11} \mathrm{H}_{24}$ & $-25,6$ & 195,8 & 0,7404 \\
\hline
\end{tabular}

Uma forma simples de separar os constituintes básicos do petróleo é promover uma destilação da amostra. Com isso, obtêm-se curvas de destilação características, que são gráficos de temperatura versus volume percentual de material evaporado. Determinam-se, assim, os tipos de hidrocarbonetos presentes na amostra analisada, em função das faixas de temperatura dos materiais destilados. A amostra poderá então ser classificada em termos de cortes ou frações, conforme Tabela 2. 
Tabela 2 - Faixa de temperatura e respectivas frações.

\begin{tabular}{cc}
\hline \hline Temperatura & Fração \\
\hline$<33^{\circ} \mathrm{C}$ & Butanos e inferiores \\
$33-105^{\circ} \mathrm{C}$ & Gasolina \\
$105-158^{\circ} \mathrm{C}$ & Nafta \\
$158-233^{\circ} \mathrm{C}$ & Querosene \\
$233-427^{\circ} \mathrm{C}$ & Gasóleo \\
$>427^{\circ} \mathrm{C}$ & Resíduo \\
\hline \hline
\end{tabular}

A destilação atmosférica é normalmente a etapa inicial de transformação realizada em uma refinaria de petróleo, após dessanilização e pré-aquecimento. 0 diagrama a seguir oferece uma listagem dos tipos de produtos esperados e seu destino.

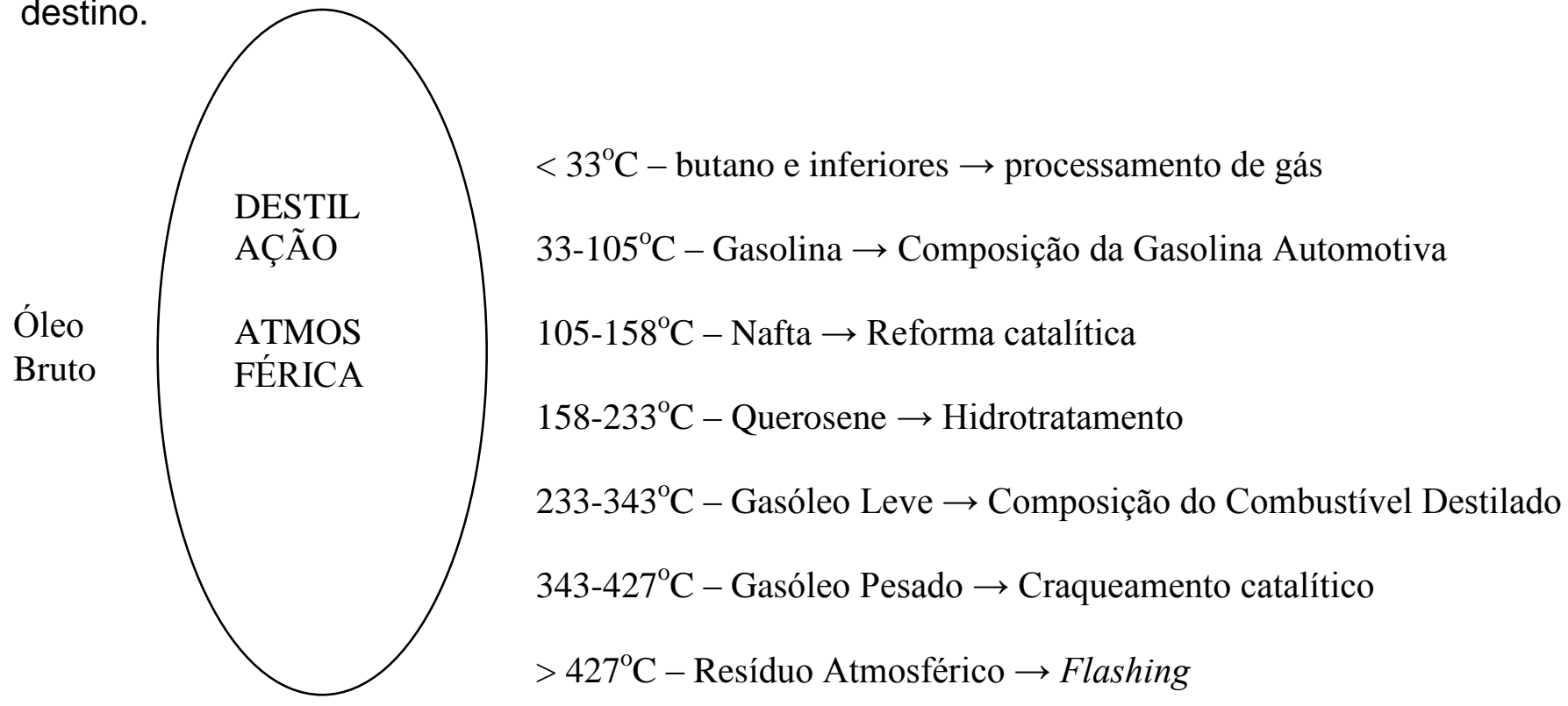

Uma amostra de petróleo e mesmo frações podem ser ainda caracterizadas pelo grau de densidade API ( $\left.{ }^{\circ} \mathrm{API}\right)$, do American Petroleum Institute, definida por: 
${ }^{\circ} \mathrm{API}=141,5 /$ densidade especifica $-131,5$

A densidade específica do material é calculada tendo-se como referência a água. Obviamente, quanto maior o valor de ${ }^{\circ} \mathrm{API}$, mais leve é o composto, conforme indica a Tabela 3 (CAMPOS, 1990).

Tabela 3 - Densidade específica conforme composto.

\begin{tabular}{cc}
\hline Asfalto & $10^{\circ} \mathrm{API}$ \\
\hline Óleo bruto pesado & $18{ }^{\circ} \mathrm{API}$ \\
Óleo bruto leve & $36{ }^{\circ} \mathrm{API}$ \\
Nafta & $50{ }^{\circ} \mathrm{API}$ \\
Gasolina & $60{ }^{\circ} \mathrm{API}$ \\
\hline \hline
\end{tabular}

Dessa forma, uma amostra de petróleo pode ser classificada segundo o grau de densidade API, como segue:

Petróleos leves: acima de $30{ }^{\circ} \mathrm{API}\left(<0,72 \mathrm{~g} / \mathrm{cm}^{3}\right)$

Petróleos Médios: entre 21 e $30{ }^{\circ} \mathrm{API}$

Petróleos Pesados: abaixo de $21{ }^{\circ} \mathrm{API}\left(>0,92 \mathrm{~g} / \mathrm{cm}^{3}\right)$

Segundo o teor de enxofre da amostra, tem-se a seguinte classificação para o óleo bruto:

Petróleos doces (sweet): teor de enxofre $<0,5 \%$ de sua massa

Petróleos ácidos (sour): teor de enxofre $>0,5 \%$ em massa 
Em especial, o índice de acidez naftênica expressa a quantidade de $\mathrm{KOH}$, em miligramas, necessária para retirar a acidez de uma amostra de $1 \mathrm{~g}$ de óleo bruto.

E também, segundo a razão dos componentes químicos presentes no óleo, pode-se estabelecer a seguinte classificação:

Óleos parafínicos: alta concentração de hidrocarbonetos parafínicos, comparada às de aromáticos e naftênicos;

Óleos naftênicos: apresentam teores maiores de hidrocarbonetos naftênicos e aromáticos do que em amostras de óleos parafínicos;

Óleos asfálticos: contêm uma quantidade relativamente grande de compostos aromáticos polinucleados, alta concentração de asfaltenos e menor teor relativo de parafinas.

Outras grandezas também definem um tipo de óleo bruto. Entre elas, citamse:

Teor de sal: podendo ser expresso em miligramas de $\mathrm{NaCl}$ por litro de óleo, indica a quantidade de sal dissolvido na água presente no óleo em forma de emulsão;

Ponto de fluidez: indica a menor temperatura que permite que o óleo flua em determinadas condições de teste;

Teor de cinzas: estabelece a quantidade de constituintes metálicos no óleo após sua combustão completa.

Os principais derivados do petróleo e seus usos são mostrados no Quadro a seguir: 
Quadro 2 - Principais derivados do petróleos e suas principais aplicações. (CAMPOS, 1990)

\begin{tabular}{|l|l|}
\hline \multicolumn{1}{|c|}{ Derivado } & \multicolumn{1}{c|}{ Uso Principal } \\
\hline Gasolina & Combustível automotivo \\
\hline Óleo Diesel & Combustível automotivo \\
\hline Óleo Combustível & $\begin{array}{l}\text { Industrial, naval, geração de } \\
\text { eletricidade }\end{array}$ \\
\hline Gás Liquefeito de Petróleo (GLP) & Cocção \\
\hline Querosene de aviação & Combustível aeronáutico \\
\hline Querosene de iluminante & Iluminação \\
\hline \multicolumn{2}{|c|}{ Insumo Petroquímico } \\
\hline Parafina & Velas, indústria alimentícia \\
\hline Nafta & Matéria-prima petroquímica \\
\hline Propeno & Matéria-prima para plásticos e tintas \\
\hline \multicolumn{2}{|c|}{ Outros } \\
\hline Óleos Lubrificantes & Lubrificação de óleos e motores \\
\hline Asfalto & Pavimentação \\
\hline
\end{tabular}

\subsection{INDÚSTRIA DO PETRÓLEO}

A indústria do petróleo é composta de cinco segmentos constitutivos básicos: exploração, explotação, transporte, refino e distribuição.

A exploração envolve a observação das rochas e a reconstrução geológica de uma área, com o objetivo de identificar novas reservas petrolíferas. Os métodos comuns empregados para se explorar petróleo são o sísmico, o magnético, o gravimétrico e o aerofotométrico. 
O petróleo é encontrado em equilíbrio com excesso de gás natural (gás associado ou livre), água e impurezas, e contém certa quantidade de gás dissolvido (gás em solução) e água emulsionada. A quantidade relativa dessas fases determina o tipo de reservatório.

Durante a explotação, são empregadas técnicas de desenvolvimento e produção de reserva após comprovação de sua existência. O poço é então perfurado e preparado para produção, caracterizando a fase de completação (CAMPOS, 1990).

Em reservas terrestres, dependendo das condições físicas do poço a produção é feita através de bombeamento mecânico, injeção de gás ou injeção de água.

Em reservas marítimas, por sua vez, a produção poderá ser feita em plataformas fixas, plataformas auto-eleváveis (em águas rasas: aproximadamente $90 \mathrm{~m}$ ) ou plataformas semi-submersíveis, e auxiliada por navios-sonda. Em determinados casos, pode haver integração entre esses métodos e adaptações.

A produção é então transportada em embarcações, caminhões, vagões, navios-tanque ou tubulações (oleodutos ou gasodutos) aos terminais e refinarias de óleo ou gás.

O refino do petróleo compreende uma série de operações físicas e químicas interligadas entre si que garantem o aproveitamento pleno de seu potencial energético através da geração dos cortes, ou produtos fracionados derivados, de composição e propriedades físico-químicas determinadas. Refinar petróleo é, portanto, separar suas frações e processá-las, transformando-o em produtos de grande utilidade.

Os produtos finais das refinarias são finalmente encaminhados às distribuidoras, que os comercializarão em sua forma original ou aditivada (CAMPOS, 1990). 


\subsection{REFINO DO PETRÓLEO}

Os objetivos básicos de uma refinaria de petróleo são: produção de combustíveis e matérias-primas petroquímicas e produção de lubrificantes básicos e parafinas.

Em função da maior necessidade de obtenção de frações que originem GLP, gasolina, diesel, querosene, óleo combustível e correlatos, na maior parte dos casos encontram-se refinarias que se dedicam principalmente à produção de combustíveis e matérias-primas petroquímicas.

Apesar das frações básicas lubrificantes e parafinas apresentarem maior valor agregado que os combustíveis, tornando este tipo de refino uma atividade altamente rentável, os investimentos necessários para tal são muito maiores.

Assim, pode-se ter o caso dos conjuntos ou unidades especialmente dedicados à geração de lubrificantes e parafinas dentro de uma refinaria para produção de combustíveis.

Os esquemas de refino são estabelecidos em função dos tipos de processos necessários, os quais são classificados segundo quatro grupos principais: processos de separação; processos de conversão; processos de tratamento e processos auxiliares (CAMPOS, 1990). 


\subsubsection{Processos de Separação}

São processos de natureza física que têm por objetivo desmembrar o petróleo em suas frações básicas ou processar uma fração previamente produzida a fim de retirar desta um grupo específico de componentes.

O agente de separação é físico e opera sob a ação de energia, na forma de temperatura ou pressão, ou massa, na forma de relações de solubilidade com solventes.

As características dos processos de separação são tais que seus produtos, quando misturados, reconstituem a carga original, uma vez que a natureza das moléculas não é alterada.

No entanto, o investimento do processo é alto e o tempo de retorno sobre o capital investido é relativamente longo, em muitos casos superior à cinco anos.

São exemplos de processos de separação: destilação atmosférica, destilação à vácuo, desasfaltação a propano, desaromatização a furfural, desparafinação a MIBC, desoleificação a MIBC, extração de aromáticos e adsorção de parafinas lineares.

\subsubsection{Processos de Conversão}

São processos de natureza química que têm por objetivo modificar a composição molecular de uma fração com 0 intuito de valorizá-la economicamente. Através de reações de quebra, reagrupamento ou reestruturação molecular, essa fração pode ou não ser transformada em outra(s) de natureza química distinta.

Ocorrem com ação conjunta de temperatura e pressão nas reações, podendo haver ainda a presença de catalisadores, caracterizando processos catalíticos ou não-catalíticos (térmicos). 
As características dos processos de conversão são tais que seus produtos, quando misturados, não reconstituem de forma alguma a forma original, uma vez que a natureza das moléculas é profundamente alterada.

Sua rentabilidade é elevada, principalmente devido ao fato que frações de baixo valor comercial (gasóleos e resíduos) são transformadas em outras de maior valor (GLP, naftas, querosene e diesel).

São exemplos de processo de conversão: processos térmicos e processos catalíticos. Os processos térmicos envolvem: craqueamento térmico, viscorredução e coqueamento retardado. Os processos catalíticos envolvem: craqueamento catalítico, hidrocraqueamento catalítico, hidrocraqueamento catalítico brando, alcoilação ou alquilação catalítica e reforma catalítica. Estes dois últimos são considerados processos de síntese e rearranjo molecular, enquanto todos os demais envolvem processo de desintegração (CAMPOS, 1990).

\subsubsection{Processos de Tratamento}

Muitas vezes as frações obtidas nos processos de separação e conversão contêm impurezas presentes em sua composição na forma de compostos de enxofre e nitrogênio que thes conferem propriedades indesejáveis como corrosividade, acidez, odor desagradável, alteração de cor e formação de substâncias poluentes.

Os processos de tratamento ou de acabamento, de natureza química, são portanto empregados com o objetivo de melhorar a qualidade dos produtos através da redução dessas impurezas, sem causar profundas modificações nas frações.

Quando utilizados em frações leves, como GLP, gases e naftas, os processos de tratamento não requerem condições operacionais severas nem grandes investimentos (processos convencionais). Os agentes responsáveis pelo 
tratamento podem ser hidróxidos de metais alcalinos ou etanolaminas, por exemplo.

Quando utilizadas em frações médias (querosene e diesel) ou pesadas (gasóleos, lubrificantes, resíduos), os processos de tratamento convencionais são ineficazes e novos processos utilizados necessitam de condições operacionais mais severas e maiores investimentos.

Nesse caso, o agente responsável pela eliminação de impurezas é geralmente o hidrogênio (hidroprocessamento), atuando na presença de um catalisador. Este processo é conhecido por hidrotratamento ou hidroacabamento e promove uma acentuada melhoria na qualidade dos produtos.

Quanto ao grau de remoção do teor de enxofre da carga, os processos de tratamento são divididos em duas classes: processos de adoçamento e de dessulfurização.

Os processos de adoçamento são usados para transformar compostos agressivos de enxofre ( $\mathrm{S}, \mathrm{H}_{2} \mathrm{~S}, \mathrm{R}-\mathrm{SH}$ ) em outros menos nocivos (RSSRdissulfetos), sem retira-los do produto.

Os processos de dessulfurização são usados na remoção efetiva dos compostos de enxofre.

São exemplos de processos de tratamento, portanto: tratamento cáustico, tratamento Merox, tratamento Bender, Tratamento DEA, hidrotratamento (HDT).

\subsubsection{Processos Auxiliares}

Os processos auxiliares existem com o objetivo de fornecer insumos para possibilitar a operação ou efetuar o tratamento de rejeitos de outros tipos de processo já citados. 
Dois processos básicos são realizados: geração de hidrogênio, como matéria-prima para as unidades de hidroprocessamento; e recuperação de enxofre, produzindo a partir da combustão de gases ricos em $\mathrm{H}_{2} \mathrm{~S}$.

Cita-se ainda a manipulação de insumos que constituem as utilidades em uma refinaria, tais como vapor, água, energia elétrica, ar comprimido, distribuição de gás e óleo combustível, tratamento de efluentes, entre outros. Nesse caso, não se trata de uma unidade de processo propriamente dita, mas as utilidades são imprescindíveis ao seu funcionamento.

De forma resumida, pode-se dizer que a destilação é o modo mais comum de se efetuar a primeira fase desta separação. Outros processos podem vir em seqüência. Além dos processos de separação, onde as moléculas do petróleo in natura não são modificadas, existem outros que as modificam, como o craqueamento (onde moléculas com grandes cadeias carbônicas são quebradas em cadeias menores) e a reforma (onde o arranjo atômico é modificado, dando nova forma a molécula). Na Figura 2 tem-se a estrutura destes dois últimos processos, hidrocraqueamento e reforma. No final de todos estes processos, os produtos derivados de petróleo são obtidos e comercializados.

Podem-se classificar os produtos do petróleo em: gases de refinaria, gás liquefeito de petróleo, produtos leves, produtos intermediários e produtos pesados. Os gases de refinaria são formados em maioria por metano e etano e, em geral, consumido nas próprias refinarias em função de sua dificuldade de armazenagem (é bastante similar ao gás natural).

Gás liquefeito de petróleo (GLP) é formado em sua maioria por propano e butano; como pode ser facilmente armazenado, por se liquefazer a baixas pressões $\left(15 \mathrm{kgf} / \mathrm{cm}^{2}\right)$, geralmente é envazado e vendido para uso domiciliar. 

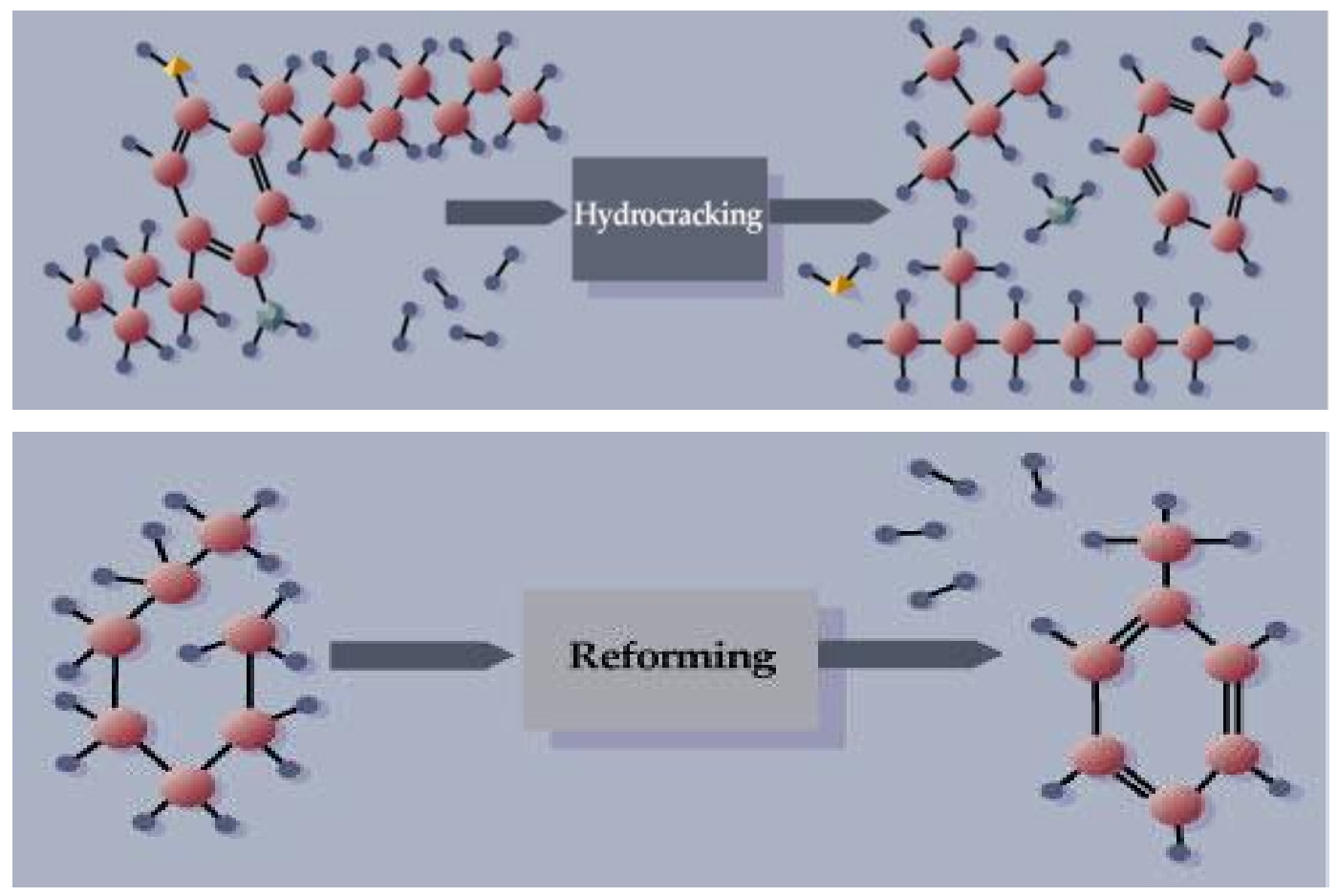

Figura 2 - Estrutura dos processos de hidrocraqueamento e reforma. (Fonte: WAUQUIE, 1995).

Produtos leves são considerados a gasolina, querosene e nafta. Produtos intermediários são considerados o óleo diesel e alguns óleos lubrificantes. Produtos pesados são considerados óleos comestíveis e alguns lubrificantes, parafina, asfalto, coque e vaselina (http//www.petrobras.com.br, 2006). A Tabela 4 apresenta a temperatura de destilação e os principais componentes obtidos.

Tabela 4 - Temperatura de destilação e respectivos componentes obtidos.

\begin{tabular}{cc}
\hline \hline Temperatura $\left({ }^{\circ} \mathrm{C}\right)$ & Componente \\
\hline $20-60$ & Éter de petróleo \\
$60-90$ & Benzina \\
$90-120$ & Nafta \\
$40-220$ & Gasolina \\
$150-300$ & Querosene \\
$100-350$ & Diesel/Gasóleo \\
$300-400$ & Óleos lubrificantes \\
Resíduos & Asfalto e coque \\
Subprodutos & Parafina e vaselina \\
\hline \hline
\end{tabular}

FONTE: http//www.petrobras.com.br, 2006 


\section{CONSIDERAÇÕES GERAIS DA GASOLINA}

Originalmente, a gasolina era um produto secundário e indesejado da indústria de refino de petróleo, que estava interessada, principalmente, no querosene. Com o advento dos motores de combustão interna, a gasolina foi eleita como a melhor opção para combustível devido as suas características de alta energia de combustão, alta volatilidade e compressibilidade.

Até 1912, toda a gasolina era obtida por processos de separação dos compostos presentes naturalmente no petróleo cru, ou por condensação de hidrocarbonetos do gás natural. Esta gasolina foi chamada de straight-run (SPEIGHT, 1999).

Neste mesmo ano, William M. Burton descobriu que se porções pesadas do óleo cru, como o gasóleo, fossem aquecidas sob pressão as grandes moléculas seriam "quebradas", ou craqueadas, em pequenas moléculas no range adequado para a fabricação da gasolina. Desta forma, a gasolina passou a ser produzida, e não mais apenas separada.

A primeira gasolina craqueada termicamente foi vista como um produto inferior devido a sua relativa instabilidade de estocagem, até que se descobriu que esta possuía um índice antidetonante maior que a de straight-run.

Em 1930, foi introduzida uma mudança no craqueamento térmico, chamada de reforma térmica, processo que utilizava porções mais pesadas da gasolina straight-run e porções mais leves do querosene para melhorar a octanagem e a volatilidade da gasolina.

Em 1937, foi implantado comercialmente o craqueamento catalítico, processo que proporciona um maior rendimento em gasolina de alta octanagem. Este processo recebeu grandes investimentos durante a II Guerra Mundial, pois foi o processo usado para produzir a gasolina de aviação.

Em 1949, a primeira planta de reforma catalítica foi colocada em operação, produzindo uma gasolina de maior octanagem.

Sempre buscando produzir uma gasolina de alta octanagem, processos antigos foram melhorados e outros foram desenvolvidos, como a polimerização e a alquilação. Polimerização consiste na ligação de pequenas moléculas de 
hidrocarbonetos olefínicos, como propeno ou buteno, vindos do processo de craqueamento para produzir moléculas maiores, formando gasolina polimerizada. A alquilação difere da polimerização por combinar olefinas e isoparafinas, normalmente o isobutano.

A gasolina distribuída por todo o país provém, em sua quase totalidade, das refinarias da Petrobras. O restante é fornecido por duas outras refinarias privadas: a de Manguinhos, no Rio de Janeiro, e a da Ipiranga, no Rio Grande do Sul.

\subsection{COMPOSIÇÃO QUÍMICA DA GASOLINA}

A gasolina é uma mistura complexa de hidrocarbonetos voláteis, cuja composição relativa e características dependem da natureza do petróleo que a gerou, dos processos de refino e da finalidade para a qual foi produzida. Obtida do refino do petróleo, é constituída basicamente por hidrocarbonetos entre 4 a 12 átomos de carbono, cuja faixa de destilação varia de 30 a $220^{\circ} \mathrm{C}$ sob pressão atmosférica. Possui também contaminantes naturais em baixas concentrações, formadas por compostos contendo enxofre, oxigênio, metais e nitrogênio.

De acordo com a estrutura molecular, os hidrocarbonetos presentes na gasolina são divididos em quatro classes:

- Parafinas Normais e Ramificadas: hidrocarbonetos saturados de cadeia linear.

- Ciloparafinas ou Naftênicos: hidrocarbonetos saturados de cadeia cíclica.

- Olefinas: hidrocarbonetos com dupla ligação carbono-carbono. Altos teores de olefinas são responsáveis pela instabilidade química da gasolina, pois apresentam a tendência de reagirem entre si e com outros hidrocarbonetos na presença de oxigênio, luz ou calor, gerando polímeros (goma) (SOUZA, 2004).

- Aromáticos: substâncias que possuem o anel benzênico em sua estrutura molecular. Os compostos aromáticos possuem a tendência de gerar mais fumaça e depósitos de carbono durante a queima no motor, comparativamente ao verificado para compostos saturados e olefínicos. 
Uma gasolina para consumo é constituída pela mistura de dois, três ou mais componentes obtidos nesses diferentes processos de refinação; pode ainda receber a adição de outros compostos como o tolueno ou xilenos, alcoóis como o metanol ou etanol anidros, além de outros aditivos especiais com finalidades específicas, entre os quais alguns antioxidantes, antidetonantes, detergentes, anticongelantes, desativadores de metal, corantes entre outros (VIDAL, 1999).

Com o agravamento da poluição causada pelos gases de escape dos veículos, a partir da década de 1970 foram intensificados os esforços, em todo o mundo, para diminuí-la. As entidades governamentais de proteção ao meio ambiente estabeleceram limites para a emissão dos principais poluentes: o $\mathrm{CO}$ (monóxido de carbono), os HC (hidrocarbonetos não queimados) e os NOx (óxidos de nitrogênio). Essas limitações, cada vez mais severas, obrigaram os fabricantes de veículos a aprimorarem os projetos de seus motores e a lançar mão de dispositivos especiais, os conversores catalíticos, para reduzir os poluentes.

Desta forma, tornou-se necessária a eliminação dos derivados de chumbo da gasolina, já que esse metal envenena os catalisadores utilizados além de ser danoso ao meio ambiente. A composição da gasolina sofreu novas alterações, já que era preciso manter a octanagem elevada sem usar CTE ou CTM (chumbotetraetila e chumbotetrametila). Os teores de olefinas e aromáticos foram aumentados. Novos aditivos surgiram como o MTBE (éter metiltercbutila), o ETBE (éter etiltercibutila), o TBA (álcool tercbutílico), MMT (metilpentadienilmanganês tricarbonila) entre outros.

A formulação da gasolina automotiva pode demandar a utilização de diversas correntes nobres do processamento do petróleo. O Quadro 3 mostra as principais correntes formadoras da gasolina, bem como suas propriedades e processos de obtenção (PETROBRÁS, 2005). Além destas correntes, a gasolina Tipo $C$ recebe a adição de álcool etílico anidro combustível (AEAC), um composto antidetonante, podendo também incluir outros aditivos. 
Quadro 3 - Composição da gasolina, segundo o processo de obtenção (PETROBRAS, 2005).

\begin{tabular}{|c|c|c|c|}
\hline Constituintes & Processo de Obtenção & $\begin{array}{l}\text { Faixa de } \\
\text { Ebulição } \\
\left({ }^{\circ} \mathrm{C}\right)\end{array}$ & $\begin{array}{l}\text { Índice de } \\
\text { Octano } \\
\text { (Motor) }\end{array}$ \\
\hline Butano & Destilação e processos de transformação & Zero & 101 \\
\hline Isopentano & $\begin{array}{l}\text { Destilação, processos de transformação, } \\
\text { isomerização }\end{array}$ & 27 & 75 \\
\hline Nafta Alquilada & $\begin{array}{l}\text { Alquilação: processo que combina } \\
\text { olefinas e parafinas }\end{array}$ & $40-150$ & $90-100$ \\
\hline $\begin{array}{l}\text { Nafta Leve de } \\
\text { Destilação }\end{array}$ & Destilação & $30-120$ & $50-65$ \\
\hline $\begin{array}{l}\text { Nafta Pesada de } \\
\text { Destilação }\end{array}$ & Destilação & $90-120$ & $40-50$ \\
\hline $\begin{array}{c}\text { Nafta } \\
\text { Hidrocraqueada }\end{array}$ & $\begin{array}{l}\text { Hidrocraqueamento: processo que } \\
\text { produz compostos saturados e reduz o } \\
\text { teor de enxofre e nitrogênio }\end{array}$ & $40-220$ & $80-85$ \\
\hline $\begin{array}{c}\text { Nafta Craqueada } \\
\text { Cataliticamente }\end{array}$ & $\begin{array}{l}\text { Craqueamento catalítico: produz uma } \\
\text { gasolina com melhores características } \\
\text { antidetonantes do que a nafta leve }\end{array}$ & $40-220$ & $78-80$ \\
\hline Nafta Polímera & $\begin{array}{l}\text { Polimerização de olefinas gasosas em } \\
\text { moléculas maiores }\end{array}$ & $60-220$ & $80-100$ \\
\hline $\begin{array}{l}\text { Nafta Craqueada } \\
\text { Termicamente }\end{array}$ & Craqueamento térmico & $30-150$ & $70-76$ \\
\hline Nafta Reformada & $\begin{array}{l}\text { Reforma catalítica, processo usado para } \\
\text { melhorar as propriedades antidetonantes } \\
\text { das gasolinas obtidas do craqueamento e } \\
\text { da destilação direta através da formação } \\
\text { de hidrocarbonetos aromáticos }\end{array}$ & $40-220$ & $80-85$ \\
\hline
\end{tabular}

Vários processos podem ser usados para obter a gasolina a partir do petróleo, Figura 3. Os processos de refinação sofreram uma contínua evolução simultaneamente com o progresso dos motores; à medida que o projeto dos mesmos sofria modificações, principalmente com relação a sua taxa de compressão, visando maior potência, os refinadores aperfeiçoavam os processos de fabricação de gasolina a fim de satisfazer os requisitos de qualidade. Ao mesmo tempo o maior consumo de gasolina levou ao desenvolvimento de processos permitindo maiores rendimentos. 


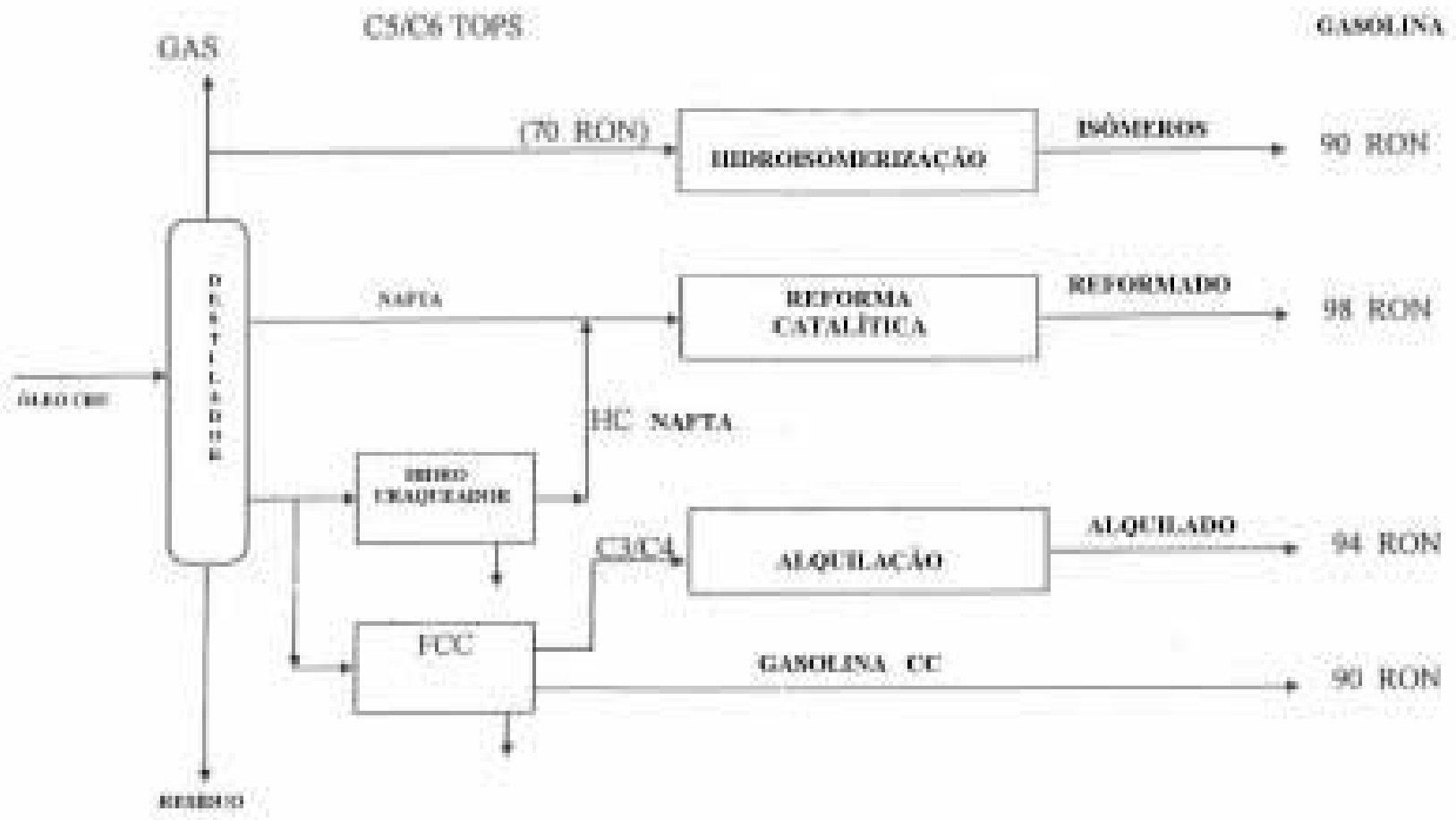

Figura 3 - Principais processos de refinação de gasolinas.

Essas metas levaram ao estado atual da indústria da refinação do petróleo, constituindo uma das mais eficientes e complexas tecnologias. Os principais processos usados para produção de gasolina são: destilação, recuperação da gasolina natural, craqueamento, hidrocraqueamento, reforma, alcoilação ou alquilação, polimerização e isomerização. A seguir será apresentado cada processo.

\subsection{DESTILAÇÃO}

O petróleo aquecido a $350^{\circ} \mathrm{C}-400^{\circ} \mathrm{C}$ é bombeado para uma torre de fracionamento onde, à pressão atmosférica é separado em várias frações: gasolina de destilação direta ou primária, querosene, óleo diesel, gasóleo e cru reduzido. 
Tanto a quantidade como a composição de hidrocarbonetos da gasolina primária dependem do tipo de petróleo destilado. Assim sendo, estas gasolinas diferem bastante em suas propriedades, como densidade, características de vaporização, poder antidetonante entre outras.

\subsection{RECUPERAÇÃO DA GASOLINA NATURAL}

O gás proveniente dos poços petrolíferos arrasta certa quantidade de hidrocarbonetos da faixa da gasolina. Estes hidrocarbonetos constituem a gasolina natural, possível de ser recuperada por vários processos.

A grande quantidade de hidrocarbonetos parafínicos de cadeia linear, existentes na gasolina natural, a torna altamente volátil comprometendo seu poder antidetonante e, por este motivo, limita sua quantidade na gasolina final.

\subsection{CRAQUEAMENTO}

Este processo consiste em provocar a "ruptura" ou "quebra" das moléculas de hidrocarbonetos de alto ponto de ebulição para produzir outro de menor ponto de ebulição na faixa da gasolina. Pode-se utilizar o processo térmico ou catalítico. O craqueamento catalítico, usado modernamente permite o uso de pressões mais baixas do que o craqueamento térmico.

A gasolina de craqueamento catalítico constitui um excelente componente para mistura final, pois tem elevado índice de octano. Os hidrocarbonetos parafínicos e naftênicos da carga de alimentação, de baixa octanagem, são convertidos em sua maioria em olefinas e aromáticos de alto índice de octano.

As gasolinas de craqueamento catalítico possuem índices de octano na ordem de 92 a 94, antes da adição de antidetonante. Possuem uma suscetibilidade razoável ao chumbo tetraetila (CTE) aumentando seu índice de 
octanagem de 5 a 7 unidades, com a adição de $0,8 \mathrm{~mL} / \mathrm{L}$ desse composto, mas a sua adição não é mais permitida na maioria dos países, inclusive no Brasil.

\subsection{HIDROCRAQUEAMENTO}

Consiste em craquear frações pesadas de petróleo em presença de hidrogênio e de um catalisador. Este processo aumenta a flexibilidade dos refinadores e permite operar uma grande variedade de cargas como gasóleos virgens, óleos de reciclagem, gasóleo de craqueamento, entre outros.

As frações produzidas no hidrocraqueamento são muito estáveis; entretanto se elas forem constituir parte substancial da gasolina final, deverão ser submetidas aos processos de reforma para melhorar o índice de octano, por elas não possuírem as olefinas ramificadas de alta octanagem que estão presentes nos produtos oriundos do craqueamento catalítico.

\subsection{REFORMA}

Todos os processos de reforma têm a mesma finalidade: converter frações de hidrocarbonetos de baixa octanagem da faixa da gasolina em frações de octanagem elevada. Normalmente, as cargas das unidades de reforma são destilados primários de faixa 93 a $204^{\circ} \mathrm{C}$, pois as frações mais leves não são adequadas.

A reforma pode ser térmica, em desuso, ou catalítica. A melhoria de octanagem advém, principalmente, do craqueamento das parafinas pesadas de baixa octanagem, formando parafinas e olefinas mais leves de elevada octanagem.

$\mathrm{Na}$ reforma catalítica, as reações de melhoria de octanagem incluem rearranjos moleculares, bem como, ruptura de moléculas. Dependendo do 
catalisador utilizado e das condições de operação as seguintes reações podem ocorrer:

-os naftênicos perdem hidrogênio transformando-se nos aromáticos correspondentes de octanagem mais alta;

-as parafinas de cadeia normal sofrem rearranjos para dar seus isômeros de cadeia ramificada;

-as parafinas pesadas de baixo índice de octano são hidrocraqueadas para dar parafinas mais leves de maior octanagem;

-as parafinas pesadas perdem hidrogênio e formam anéis transformando-se em aromáticos de elevada octanagem.

\subsection{ALQUILAÇÃO OU ALCOILAÇÃO}

Neste processo são produzidos hidrocarbonetos de cadeia maior partindo de outros menores, isto é, líquidos na faixa da gasolina a partir de gases de refinaria são obtidos. É um processo caro, mas o produto final alquilado tem excelentes características antidetonantes. $O$ produto de alquilação tem índice de octano de 95, sem adição de álcool e 106/107, com álcool etílico (VIDAL, 1999).

\subsection{POLIMERIZAÇÃO}

De modo semelhante à alquilação, a polimerização é um processo para fazer gasolina a partir de gases de refinaria. Mas, na polimerização, somente reagem os gases olefínicos, ligando suas moléculas para formar líquidos olefínicos. Os gases parafínicos de alimentação não se alteram durante o processo. É pouco usado industrialmente e, no Brasil, não existe nenhum processo de polimerização para produzir gasolina. 


\subsection{ISOMERIZAÇÃO}

Este processo converte hidrocarbonetos de cadeia linear em seus isômeros de cadeia ramificada. O composto sofre uma reestruturação sem alterar sua massa molecular. Assim, o heptano normal que tem índice de octano zero (um dos padrões na escala de índice de octano) pode ser isomerizado dando uma mistura de isoheptanos, algum dos quais possuindo índice de octano superior a 100. A Figura 4 mostra como se distribuem os diferentes tipos de hidrocarbonetos nas gasolinas (naftas) obtidas pelos diversos processos (Fonte: V. B. Guthrie - Petroleum Products Handbook), sendo a gasolina final constituída pelas misturas das gasolinas (naftas) obtidas nos vários processos de produção, cuja composição final dependerá das proporções em que estes constituintes sejam misturados no pool de gasolinas.

\section{Destilaçăo direla \\ Craqueamenlo térmico \\ Craqueamenio calalilico \\ Rolormaça calalilica \\ Gasolina (nalla) de alquilaçáo Gasolina (nalla)
polimera}
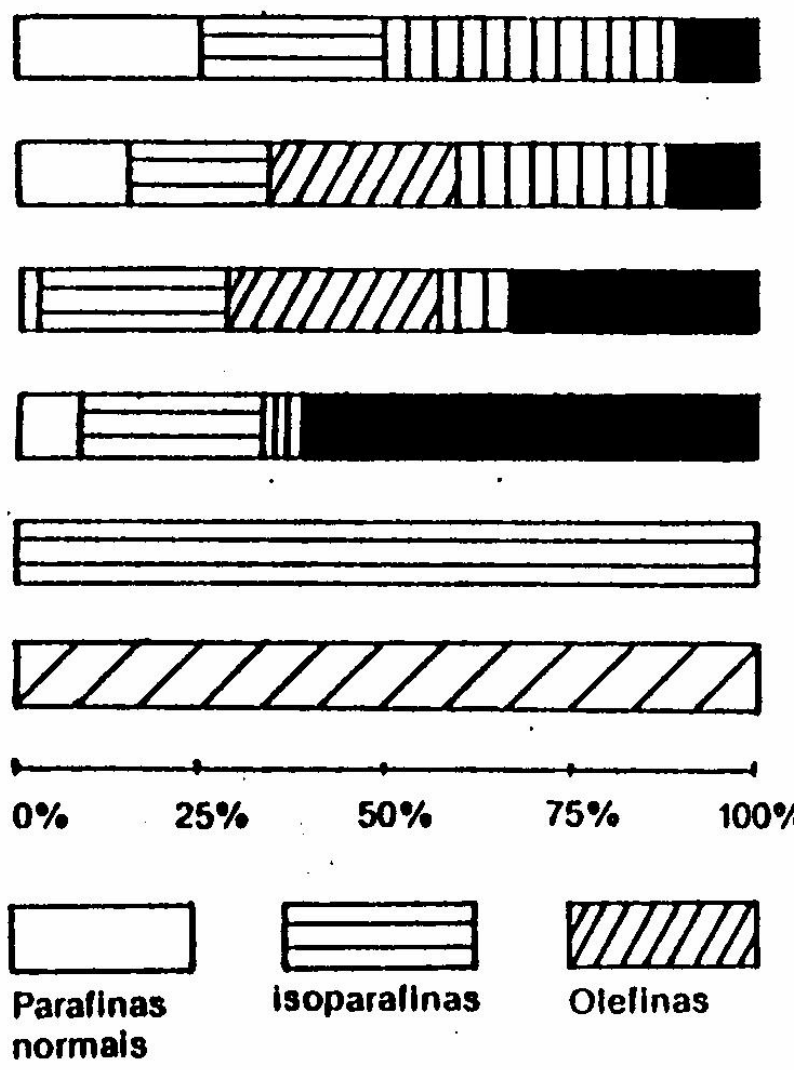

Nallénicos

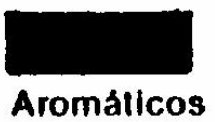

Figura 4 - Distribuição de hidrocarbonetos em gasolinas 


\subsection{OCTANAGEM}

Octanagem é uma propriedade do combustível que representa sua capacidade de resistir à compressão sem entrar em auto-ignição. Um combustível com maior octanagem possui melhor poder de combustão e resiste a altas pressões no interior dos cilindros sem sofrer detonação. Os projetistas de motores levam em conta a octanagem do combustível utilizado para determinar a taxa de compressão, curvas de avanço de ignição (representação gráfica do avanço da ignição ao longo da faixa de operação do motor), tempo de injeção (PETROBRÁS, 2005).

Um combustível com elevada octanagem:

- Deve ser empregado em motores que operam com maiores razões de compressão. Isso favorece o rendimento térmico através do maior aproveitamento do calor liberado na combustão;

- Possibilita uma combustão não detonante, ou seja, a queima espontânea da mistura combustível conhecida como "batida de pino", evitando, assim, danos ao motor;

- Permite o aumento de torque, potência e economia devido ao crescimento do rendimento térmico.

A octanagem da gasolina é determinada pelos métodos MON, RON e IAD (ANP, 2005).

O método MON (Motor Octane Number) avalia a resistência á detonação da gasolina na situação em que o motor está em plena carga e alta rotação. $O$ Método RON (Research Octane Number) avalia a resistência à detonação da gasolina na situação em que o motor está carregado e em baixa rotação (até 3000 rpm). IAD (Índice Antidetonante) é a média aritmética dos anteriores.

Convencionou-se atribuir índice de octanas zero ao n-heptano que é uma substância pouco resistente à compressão e índice 100 ao iso-octano. Logo, misturas de $\mathrm{n}$-heptano e iso-octano servem como um sistema de referência para a gasolina, fornecendo uma escala antidetonante. Um combustível que apresente 
índice de octanas igual a 91 queima como se fosse constituído por uma mistura de $9 \%$ de $n$-heptano e $91 \%$ de iso-octanos (2,2,4-trimetilpentano).

Parafinas em geral apresentam baixa octanagem. Parafinas normais têm as piores propriedades antidetonantes, piorando á medida que a massa molecular aumenta. As isoparafinas têm uma octanagem um pouco maior que as normais, aumentando á medida que o grau de ramificação aumenta. As olefinas têm maior octanagem do que as parafinas. Aromáticos, normalmente, possuem os maiores índices antidetonantes.

No Brasil, ao se falar em octanagem, está sendo referido a octanagem MON. Alguns países utilizam a octanagem RON, e outros o índice anti detonante - $I A D=(M O N+R O N) / 2$. Para uma mesma gasolina, o Ron tem um valor típico superior ao MON de até 10 octanas. Portanto, ao se comparar gasolinas de diferentes países é importante especificar a base (MON, RON ou Índice Antidetonante). Além da octanagem, outros fatores devem ser considerados para a produção de uma gasolina de qualidade elevada, como, por exemplo, a sua volatilidade, estabilidade e sua corrosividade, de forma a garantir o funcionamento adequado dos motores.

\subsection{TIPOS DE GASOLINA}

Os tipos de gasolina são oferecidos aos consumidores de acordo com as principais características de projeto dos motores, em função da taxa de compressão do motor e de outras variáveis que afetam a temperatura e pressão dentro do motor, além do tipo de sistema de injeção de combustível.

Os tipos de gasolina são atualmente especificados pela Agência Nacional de Petróleo (ANP) e indica cinco tipos de gasolina para automóveis, sendo estas: Tipo A, Tipo A Premium, Tipo C, Tipo C Premium e Tipo C Podium (nome comercial) (http//www.br.com.br, 2006).

A gasolina Tipo A é produzida pelas refinarias de petróleo e entregue diretamente às companhias distribuidoras antes da adição do etanol anidro. Esta 
gasolina constitui-se basicamente de uma mistura de naftas numa proporção tal que enquadre o produto na especificação prevista. Este produto é a base da gasolina disponível nos postos revendedores. A gasolina Tipo A Premium é a gasolina que apresenta uma formulação especial. Ela é obtida a partir da mistura de naftas de elevada octanagem (nafta craqueada, alquilada e reformada) e que fornecem ao produto maior resistência a detonação, do que aquela fornecida pela gasolina Tipo $C$ comum. Esta gasolina é entregue diretamente às companhias distribuidoras e constitui a base da gasolina C Premium, disponibilizada para os consumidores finais nos postos de revenda.

Gasolina Tipo C é a gasolina comum que se encontra disponível no mercado, sendo comercializada nos postos revendedores e utilizada em automóveis, entre outras. Esta gasolina é preparada pelas companhias distribuidoras que adicionam álcool etílico anidro à gasolina Tipo A. $\mathrm{O}$ teor de álcool na gasolina final atinge à faixa de 24 a $26 \%$ em volume, conforme prevê a legislação atual (Resolução 35 do CIMA - Conselho Interministerial do Açúcar e Álcool, de 2006). Esta gasolina apresenta uma octanagem no mínimo igual a 80 (MON).

Gasolina Tipo C de Alta Octanagem - ela possui octanagem maior que a gasolina comum e com teor de enxofre menor, o que reduz as emissões de poluentes no meio ambiente. Pode ser utilizada em qualquer veículo movido à gasolina, mas o melhor desempenho do motor oferecido pela alta octanagem só será percebido por veículos cujos motores sejam adequados a este tipo de combustível. Geralmente são veículos importados e sofisticados, equipados com alta taxa de compressão (maior que 10:1). Exemplos de gasolinas de alta octanagem: Premium e Podium.

Gasolina Tipo C Premium é a gasolina elaborada pela adição de 24 a $26 \%$ de álcool anidro à gasolina Tipo A Premium. Esta gasolina foi desenvolvida com 0 objetivo principal em atender aos veículos nacionais e importados, de altas taxas de compressão e alto desempenho, e que tenham a recomendação dos fabricantes de utilizar um combustível de elevada resistência à detonação o que no caso da gasolina Premium, é expresso pelo índice antidetonante (IAD). 
As principais características que diferenciam a gasolina Tipo C Premium da gasolina Tipo C comum são: maior IAD (gasolina Tipo C Premium: 91 mínimo; gasolina Tipo C comum: 87 em média) e menor teor de enxofre (gasolina Tipo C Premium: 0,10\% máximo; gasolina Tipo $\mathrm{C}$ comum: 0,20 \% máximo).

A gasolina Premium já existe há muito tempo nos países da Europa e nos Estados Unidos. Nesses países a disponibilização pela indústria automobilística de veículos com motores de alto desempenho exige um combustível de maior desempenho, antidetonante e que possibilite atingir potência máxima prevista em seus projetos.

A característica antidetonante da gasolina Premium produzida pela Petrobrás no Brasil apresenta um desempenho no mesmo nível daquela existente na Europa e nos Estados Unidos. O que basicamente, diferencia a gasolina brasileira da gasolina existente nesses países é o produto oxigenado utilizado na mistura; enquanto lá utilizam MTBE (Metil, Terc-Butil-Éter), no Brasil utiliza-se o etanol anidro, tanto na gasolina Premium quanto na gasolina comum. As companhias distribuidoras adicionam a uma parte da gasolina Tipo A, comum ou Premium, além do álcool etílico, produtos (aditivos) que conferem à gasolina características especiais. Nesse caso, a gasolina comum passa a ser comercializada como gasolina aditivada. A gasolina Premium, quando aditivada continua a ser denominada como gasolina Premium.

$O$ aditivo multifuncional adicionado na gasolina possui, entre outras, características detergentes e dispersantes e tem a finalidade de melhorar 0 desempenho do produto. Testes efetuados em motores com a gasolina aditivada da Petrobrás distribuidora demonstraram que o aditivo contribui para minimizar a formação de depósitos nos bicos injetores, assim como no coletor e hastes das válvulas de admissão. A gasolina aditivada recebe um corante que the confere uma cor distinta daquela apresentada pela gasolina comum (a gasolina aditivada Br-SUPRA apresenta cor verde).

Lançada em 2002, a gasolina Petrobrás Podium é classificada pela Agência Nacional do Petróleo (ANP) como gasolina Tipo Premium, com características diferenciadas: octanagem de 95 unidades (IAD - Índice Antidetonante), menor teor 
de enxofre (30 mg/L) e composição especial que evita acúmulo de depósitos no motor.

Pela maior octanagem, esta gasolina permite que os veículos obtenham um melhor desempenho, principalmente nas retomadas de velocidade. Seu baixo teor de enxofre faz com que se torne uma gasolina de menor impacto ambiental.

Além dessas vantagens, em razão de sua formulação especial, a gasolina Podium também reduz o acúmulo de depósitos nos motores, possibilitando intervalos maiores entre as manutenções, e possui maior capacidade de resistir à oxidação quando comparada às gasolinas comum, aditivada e Premium.

Pode ser utilizada em qualquer veículo movido à gasolina ressaltando-se que o benefício de melhor desempenho, é percebido em veículos com alta taxa de compressão (a partir de 10:1) e que, em qualquer motor, a gasolina Podium proporciona menor emissão de fases poluentes e nenhum efeito negativo.

Semelhantemente, as demais gasolinas automotivas comercializadas no país recebem a adição de álcool anidro, na proporção determinada pela legislação vigente. Considerando que o álcool anidro está recebendo um corante de cor laranja, desde 06/01/06, a gasolina Podium que antes era incolor, passa a ser levemente alaranjada. Além destes tipos básicos, existe a gasolina padrão que é uma gasolina especialmente produzida para uso na indústria automobilística, nos ensaios de avaliação do consumo e das emissões de poluentes como gases de escapamento e hidrocarbonetos (emissões evaporativas), dos veículos por ela produzidos.

Gasolinas especiais - são utilizadas, em sua maioria, por montadoras e laboratórios para desenvolvimento de motores, em testes de desempenho, testes de emissões e também como a primeira gasolina a ser inserida no automóvel quando finalizada sua montagem, sendo:

a) Gasolina padrão - possui especificação determinada pela Agência Nacional de Petróleo (ANP) e se destina à homologação de veículos nos ensaios de emissões;

b) Gasolinas para testes de desempenho - feitas sob medida, de acordo com a especificação definida pelo cliente; 
c) Gasolinas de $1^{\circ}$. Enchimento - com alta estabilidade, é desenvolvida com especificações diversas para atender as montadoras;

d) Gasolinas para competições automotivas - gasolina para carros de corrida.

\subsection{ADULTERAÇÃO DA GASOLINA}

A adulteração da gasolina envolve a modificação de sua composição original através da adição de: álcool etílico anidro em porcentagens superiores ao estabelecido pela ANP; solventes diversos, como rafinados petroquímicos e diesel.

A prática de adulteração da gasolina iniciou-se com a abertura de mercado do setor de combustíveis, após quase meio século de monopólio, o que foi agravado pela redução do subsídio ao álcool hidratado e anidro e pela liberação da importação de solventes, tornando os custos destes bastante inferiores aos da gasolina (SANTOS, 2003). Esse processo de abertura teve como principal objetivo desenvolver um mercado competitivo no setor de combustíveis através da atuação de outras empresas que viriam a produzir ou importar derivados de petróleo, dando ao consumidor a oportunidade de escolher o fornecedor de combustíveis e estimulando a concorrência (OLIM E HADDAD, 2003).

A adição de solventes seja de um novo composto, seja pelo excesso de outro já presente naturalmente, provoca mudanças nas propriedades físicoquímicas da gasolina; entre elas, a curva de destilação, a pressão de vapor, e a taxa de equilíbrio vapor-líquido estão diretamente relacionadas à composição e às características químicas da mistura. Estas propriedades têm uma grande influência no controle da ignição, no aquecimento e aceleração do motor e no consumo de combustível.

Alguns dos "sintomas" apresentados pelo carro se este for abastecido com gasolina adulterada são: o consumo de combustível aumenta de repente e sem motivos aparentes: 0 desempenho do motor piora, principalmente em subidas; fica difícil dar a partida pela manhã; o carro morre em pequenas paradas, como 
semáforos; a combustão acontece antes do devido, o carro "bate-pino". (WIEDMANN, 2003).

A adição de etanol causa intensas mudanças nas propriedades físicoquímicas do combustível, levando a um aumento do número de octanagem, variação na massa específica e pressão de vapor, além de transformações da curva de destilação. (OLIVEIRA, 2004).

Dentre os solventes mais usados na adulteração da gasolina estão o óleo diesel, querosene, e rafinados petroquímicos (TEIXEIRA, 2001), além do solvente de borracha (DAGOSTIN, 2003) e o excesso de álcool anidro (OLIVEIRA, 2004).

Os compostos rafinados têm um baixíssimo valor de mercado, pois são frequentemente obtidos como resíduos de um processo petroquímico, o que faz com que sejam muito usados para adulteração de gasolina.

Pode-se citar como fatores motivadores da grande expansão da atividade ilícita de adulteração de combustíveis: a grande diferença de preço entre solventes e gasolina; os solventes podem ser adquiridos facilmente no mercado, não possuindo nenhuma restrição quanto à sua venda; os solventes são solúveis na gasolina, tornando difícil a detecção por simples inspeção visual; a alta incidência de impostos sobre a gasolina, levando a uma pequena margem de lucro sobre a venda do produto.

A Superintendência de Qualidade de produtos - SQP da ANP, visando o controle de qualidade, mantém contratos com Instituições - Universidades e Centros de Pesquisa, atuando em 18 estados além do Distrito federal. Nos postos visitados é coletada ao menos uma amostra de gasolina $C$ comum, e em um universo menor escolhido ao acaso, são coletadas amostras de gasolina $C$ aditivada, gasolina C Premium, óleo diesel comum e aditivado e álcool etílico hidratado comum e aditivado.

As amostras coletadas são analisadas no laboratório da Instituição contratada sendo consideradas "conformes" quando atendem a todas as características definidas nas especificações da ANP (ANP, 2005).

Para a gasolina a maioria dos casos de não conformidades, registrados no país, deve-se à curva de destilação fora das especificações, ao teor inadequado 
de álcool anidro, estando a octanagem em terceiro lugar. Os estados considerados críticos, tanto pelo porte econômico quanto pelos índices de não conformidade sistematicamente encontrados em todos os combustíveis, são os Estados de São Paulo e do Rio de Janeiro (ANP, 2005).

Tanto o querosene quanto o diesel têm temperaturas de ebulição maiores que da gasolina, ou seja, são mais pesadas. A inclusão destes compostos na gasolina aumenta o consumo de combustível e reduz o desempenho do motor devido a uma atomização ineficiente, além de causar uma corrosão prematura do tanque de combustível e de componentes internos do motor devido ao acúmulo de sujeira.

Além da ação sobre o veículo, existem outras consequências mais graves, relacionadas ao aumento das emissões de gases de combustão nocivos, como derivados de NOx e SOx, causadores de chuva ácida, e monóxido de carbono $\mathrm{CO}$, que é altamente asfixiante, devido á queima irregular da gasolina no motor. A exposição de seres humanos, que trabalham diretamente com combustíveis, a compostos prejudiciais à saúde, como o benzeno, também é fator preocupante.

Há também o efeito de cossolvência exibido pelo álcool em relação a substâncias presentes naturalmente na gasolina, como os compostos BTEX (Benzeno, Tolueno, Etil-Benzeno e Xilenos), efeito este que aumenta à medida que cresce o teor de álcool etílico na gasolina. $O$ álcool atua como um co-solvente facilitando da solubilidade destes compostos nocivos na água. No caso de um acidente, ou vazamento de tanques de combustível encontrados nos postos de distribuição, tem-se um agravamento da contaminação de lençóis freáticos da região.

Outro tipo de adulteração surgiu com a regulamentação do exercício da atividade de formulação e venda no mercado interno da gasolina $A$, comum e Premium, e do óleo diesel a partir de misturas de correntes petroquímicas, adquiridas nos mercados interno ou externo (PANP, 2001).

Esta regulamentação abre uma brecha para misturas ilegais de solventes comerciais para a formulação de uma gasolina automotiva mantendo-a dentro das especificações, como mostrado em Almeida (ALMEIDA, 2003). Os autores usaram 
uma mistura de álcool etílico anidro, thinner, aguarrás, n-pentano, n-hexano, xileno e ciclo-hexano para formular uma gasolina e mostrou que com essa composição a mistura de solventes enquadra-se em todos os parâmetros físico-químicos da especificação da gasolina.

Este tipo de fraude encontra um obstáculo apenas com programa de marcação de solventes da Agência Nacional do Petróleo (ANP), onde todo solvente vendido no país deve receber a adição de uma substância química, cuja composição é conhecida apenas pela APN. Entretanto, pode-se afirmar que se trata de um isótopo não radioativo adicionado aos solventes em concentrações de 400 ppb (CIÊNCIA-HOJE, 2000).

A presença deste marcador na gasolina somente pode ser notada através de uma corrida cromatográfica e somente se houver um padrão para comparação. Se o marcador for encontrado em uma amostra de gasolina, este recebeu a adição de pelo menos um solvente.

O número de postos de gasolina que existem no país para serem fiscalizados é bastante grande, e mesmo com o programa de marcação de solventes, as adulterações continuam a acontecer, já que fiscalizar todos os postos e recolher amostras diariamente seria impossível.

\subsection{ESPECIFICAÇÕES DA GASOLINA AUTOMOTIVA}

Os principais requisitos a que devem atender uma gasolina para assegurar um desempenho satisfatório no motor são os seguintes:

- partida à frio, rápida e fácil em qualquer rápida em qualquer clima;

- aquecimento rápido do motor;

- boas características de aceleração;

- menor tendência a causar entupimento (vapor lock) em tempo quente.

- ausência de frações pesadas a fim de evitar diluição do óleo lubrificante do cárter.

As características anteriores relacionam-se com os ensaios de destilação e pressão de vapor, e em alguns casos o ensaio de goma; 
- boas características antidetonantes, o que proporciona um máximo de potência com um mínimo de consumo, propriedade relacionada com o índice de octano;

- ausência de goma e menor tendência em produzi-la quando em armazenamento, características relacionadas, respectivamente, com os ensaios de goma atual e período de indução;

- ausência de compostos corrosivos de enxofre, características relacionadas com os ensaios de corrosividade e teor de enxofre.

A qualidade de um produto pode ser definida em termos de adequabilidade para determinada aplicação. O controle de qualidade é feito por intermédio de análises e ensaios apropriados, estes ensaios devem ser relativamente simples e ter boa precisão e reprodutibilidade.

Para garantir a qualidade do produto e um desempenho satisfatório são estabelecidas as especificações. Uma especificação eficiente pode ser definida como aquela que possibilita um controle adequado da qualidade do produto, sem ser demasiado restritiva e, ao mesmo tempo, envolve um mínimo de esforço para testá-la.

No Brasil, as propriedades para controle da qualidade da gasolina automotiva, tipo C, são especificadas através da Portaria ANP no. 309 de 27/12/2001 através do Regulamento Técnico no. 5/2001, dados no Quadro 4.

O percentual de álcool atualmente adicionado à gasolina é definido pelo Ministério da Agricultura, Pecuária e Abastecimento através da Portaria MAPA no. 554 , de 27/05/2003, que entrou em vigor a partir de 01/06/2003, e que dispõe sobre a adição de álcool etílico anidro combustível (AEAC) à gasolina, fixando em $25 \%$ com variação de $1 \%$ o percentual obrigatório de adição de álcool etílico anidro combustível à gasolina.

Este valor pode oscilar entre 20 a $25 \%$, segundo a disponibilidade de matéria-prima para a sua produção e oscilações do preço do álcool nos mercados interno e externo.

A seguir serão abordadas algumas das especificações importantes. 
Quadro 4 - Especificações da gasolina comum Tipo C. Portaria ANP nº 309.

\begin{tabular}{|c|c|c|c|}
\hline Característica & Especificação & Importância do Controle & Normas \\
\hline $\begin{array}{l}\text { Cor e Aspecto } \\
\text { (se isento de } \\
\text { corantes) }\end{array}$ & $\begin{array}{l}\text { De incolor a } \\
\text { amarelada, } \\
\text { límpido e isento } \\
\text { de impurezas }\end{array}$ & $\begin{array}{l}\text { Indica presença de contaminantes ou à oxidação de } \\
\text { compostos instáveis. Materiais em suspensão reduzem a } \\
\text { vida útil dos filtros de combustível e prejudicam o } \\
\text { funcionamento do motor. }\end{array}$ & $\begin{array}{l}\text { NBR } 7148 \\
\text { ASTM D1298 }\end{array}$ \\
\hline$\%$ AEAC (\% Vol.) & $25 \%, \pm 1 \%$ & $\begin{array}{l}\text { A adição de álcool altera a octanagem da gasolina e a } \\
\text { emissão de poluentes. }\end{array}$ & NBR 13992 \\
\hline $\begin{array}{l}\text { Massa específica } \\
\left(\mathrm{kg} / \mathrm{m}^{3}, 20^{\circ} \mathrm{C}\right)\end{array}$ & $\begin{array}{l}\text { Anotar faixa } \\
\text { típica } 740 \text { e } 776\end{array}$ & $\begin{array}{l}\text { Indica possíveis adulterações, com produtos mais leves } \\
\text { ou mais pesados. }\end{array}$ & $\begin{array}{c}\text { NBR } 7148 \\
\text { NBR } 14065 \\
\text { D1298, D4052 }\end{array}$ \\
\hline Destilação $\left({ }^{\circ} \mathrm{C}\right)$ & & \multirow{6}{*}{$\begin{array}{l}\text { Mede as características de volatilidade da gasolina, como } \\
\text { descrito na seção de Curvas de destilação }\end{array}$} & \multirow{6}{*}{$\begin{array}{l}\text { NBR } 9619 \\
\text { D86 }\end{array}$} \\
\hline $\begin{array}{l}\text { 10\% evaporado, } \\
\text { Max. }\end{array}$ & 65,0 & & \\
\hline $\begin{array}{l}50 \% \text { evaporado, } \\
\text { Max. }\end{array}$ & 80,0 & & \\
\hline $90 \%$ evaporado & $190,0-145,0$ & & \\
\hline PFE, Max. & 220,0 & & \\
\hline Resíduo, \% vol Max. & 2,0 & & \\
\hline MON, mín. & 82,0 & Indica a capacidade do combustível resistir à detoação & $\begin{array}{l}\text { MB 457, } \\
\text { D2700 }\end{array}$ \\
\hline IAD & 87,0 & $\begin{array}{l}\text { Mede o desempenho real da gasolina, pois é a média } \\
\text { entre MON (octanagem em condições severas) e o RON } \\
\text { (condições suaves). }\end{array}$ & $\begin{array}{c}\text { MB 457, } \\
\text { D2700, D2699 }\end{array}$ \\
\hline $\begin{array}{l}\text { Pressão de Vapor }^{1} \mathrm{a} \\
37,8^{\circ} \mathrm{C}, \mathrm{kPa} \operatorname{Max}\end{array}$ & 69,0 & $\begin{array}{l}\text { Avalia a tendência da gasolina de evaporar-se. Deve ser } \\
\text { adequada para garantir a partida fácil do motor e não } \\
\text { interromper a passagem do combustível ao sistema de } \\
\text { alimentação. }\end{array}$ & $\begin{array}{l}\text { NBR } 4149, \\
\text { NBR } 14156, \\
\text { D4953, D519, } \\
\text { D5191, D5482 }\end{array}$ \\
\hline $\begin{array}{l}\text { Goma, mg/100 mL } \\
\text { máx. }\end{array}$ & 69,0 & $\begin{array}{l}\text { Avalia a tendência da gasolina de evaporar-se. Deve ser } \\
\text { adequada para garatnir a partida fácil do motor e não } \\
\text { interromper a passagem do combustível ao sistema de } \\
\text { alimentação. }\end{array}$ & $\begin{array}{l}\text { NBR14525, } \\
\text { D381 }\end{array}$ \\
\hline $\begin{array}{l}\text { Período de indução a } \\
100^{\circ} \mathrm{C} \text {, minutos }\end{array}$ & 360 & $\begin{array}{l}\text { Indica o período de vida útil da gasolina durante a } \\
\text { estocagem }\end{array}$ & $\begin{array}{l}\text { NBR } 14478, \\
\text { D525 }\end{array}$ \\
\hline $\begin{array}{l}\text { Corrosividade ao } \\
\text { cobre a } 50^{\circ} \mathrm{C}, 3 \mathrm{~h} \\
\text { Max. }\end{array}$ & 1 & $\begin{array}{l}\text { Verifica a tendência à corrosão nas partes metálicas do } \\
\text { motor. }\end{array}$ & $\begin{array}{l}\text { NBR14359, } \\
\text { D130 }\end{array}$ \\
\hline $\begin{array}{l}\text { Enxofre, \% massa } \\
\text { Max. }\end{array}$ & 0,10 & $\begin{array}{l}\text { Ação corrosiva no motor, deterioração do óleo } \\
\text { lubrificante, formação e emissão de gases tóxicos. }\end{array}$ & $\begin{array}{c}\text { NBR 6563, } \\
\text { NBR 14533, } \\
\text { D1266, D54, } \\
\text { D4294, } \\
\text { D3120, D2622 }\end{array}$ \\
\hline $\begin{array}{l}\text { Benzeno, \% vol. } \\
\text { Máx. }\end{array}$ & 1,0 & Composto cancerígeno & $\begin{array}{c}\text { D3606, } \\
\text { D6277, } \\
\text { D5443, D3237 }\end{array}$ \\
\hline Chumbo, g/L & 0,005 & $\begin{array}{l}\text { Possui elevada toxidez e é um envenenador dos } \\
\text { catalisadores utilizados nos conversores catalíticos. }\end{array}$ & \\
\hline $\begin{array}{l}\text { Hidrocarbonetos, \% } \\
\text { vol. }\end{array}$ & & \multirow[t]{3}{*}{$\begin{array}{l}\text { Controlar emissões atmosféricas e inibir adição de } \\
\text { solventes }\end{array}$} & \multirow[t]{3}{*}{$\begin{array}{l}\text { MB 424, } \\
\text { D1319 }\end{array}$} \\
\hline Aromáticos, máx. & 45 & & \\
\hline Olefínicos, máx. & 30 & & \\
\hline
\end{tabular}

${ }^{1}$ Para os Estados do Rio Grande do Sul, Santa Catarina, Paraná, São Paulo, Rio de janeiro, Espírito Santo, Minas Gerais, Mato Grosso, Mato Grosso do Sul, Goiás e Tocantins, bem como para o Distrito Federal, admite-se nos meses de abril a novembro um acréscimo de 7,0 kPa ao valor máximo especificado para a Pressão de Vapor. 


\subsubsection{Cor e aspecto}

Indica a tonalidade característica do produto. No caso da gasolina tipo A e do tipo C, sem aditivos, a cor pode variar de incolor a amarelo. Quando a gasolina é aditivada, ela recebe um corante para diferenciá-la das demais, podendo apresentar cor, exceto azul (reservada para gasolina de aviação) e rosa (reservada para a mistura formada por Metanol, Etanol e Gasolina-MEG).

A gasolina aditivada comercializada pela Petrobras Distribuidora (BR) apresenta cor verde. Alterações na cor da gasolina podem ocorrer devido à presença de contaminantes ou devido à oxidação de compostos instáveis nela presente (olefinas e compostos nitrogenados).

\subsubsection{Misturas com álcool}

De modo geral, as misturas carburantes são baseadas em álcoois como etanol e metanol. No Brasil, a adição de álcool (etanol) anidro à gasolina é feita há muitos anos. Atualmente, usa-se $22 \% \pm 2 \%$ na mistura. Quando há escassez de álcool, a ANP reduz esta quantidade, como já ocorreu, quando o teor baixou para $18 \% \pm 2 \%$.

As vantagens ou desvantagens do uso de misturas gasolina-álcool nos motores de combustão interna têm sido comentadas e discutidas por inúmeros especialistas e técnicos. Aceita-se hoje que, em proporções até o máximo de 15\% ou $20 \%$ de álcool em volume, a utilização de misturas gasolinas-álcool traz vantagens apreciáveis.

Os aspectos técnicos mais interessantes de ressaltar na adição de álcool são:

- o álcool aumenta a octanagem da gasolina. Esse aumento depende da composição da gasolina e, principalmente, do nível de octanagem dela.

Nos níveis baixos de octanagem, o álcool tem excelente valor de mistura (blending value); 
-a relação ar/ combustível necessária para combustão completa do álcool é de 9:1 e da gasolina 15:1. Com porcentagens de álcool acima de 15\% na mistura, faz-se necessário ajustar e regular o carburador para operar com a mistura (1);

-a tolerância das misturas à água é muito baixa. A presença de pequenas quantidades de água provoca a separação dos dois carburantes. Uma mistura com $5 \%$ de álcool separa com apenas $0,1 \%$ de água; uma de $10 \%$ de álcool separa com $0,3 \%$ de água. A adição de benzol melhora a tolerância à água; -o álcool tem elevado calor latente de vaporização (205cal/g) comparado com a gasolina $(80 \mathrm{cal} / \mathrm{g})$, o que aumenta o esfriamento no motor influenciando favoravelmente a resistência à detonação.

-o álcool é causa de partidas mais difíceis com o motor frio, principalmente em climas frios. Por outro lado, sendo um produto de ponto de ebulição constante $\left(78,3^{\circ} \mathrm{C}\right)$ forma-se um patamar na curva de destilação aumentando a tendência ao tamponamento;

-o poder calorífico do álcool é menor do que o da gasolina pura, assim a adição de álcool aumenta o consumo do combustível;

-a contaminação do álcool com cobre, proveniente das colunas de destilação, acarreta problemas de goma nas misturas com gasolinas ricas em olefinas e diolefinas;

-o álcool reduz a poluição ambiental provocada pelas emissões de gases do escapamento dos veículos. Um estudo efetuado pela Universidade de São Paulo revelou, que no caso do etanol, a emissão de $\mathrm{CO}$ foi $65 \%$ menor, a de hidrocarbonetos $(\mathrm{HC})$ foi $69 \%$ menor e a de NOx foi $13 \%$ menor. No entanto, a emissão de aldeídos aumentou em $400 \%$ em relação à gasolina (FERNANDES, 1997). 


\subsubsection{Destilação}

O ensaio de destilação, efetuado de acordo com a norma NBR 9619, propicia uma medida, em termos de volatilidade, das proporções relativas de todos os hidrocarbonetos componentes da gasolina.

Consiste o ensaio em destilar $100 \mathrm{~mL}$ de gasolina, e registrar as temperaturas nas quais as várias porcentagens destilam.

Representando-se em gráfico as porcentagens de destilado e as temperaturas correspondentes, obtém-se a chamada curva de destilação de grande utilidade para prever o desempenho da gasolina no motor. (Figura 5).

A especificação da gasolina assinala as temperaturas máximas nas quais $10 \%, 50 \%$ e $90 \%$ do combustível devem estar evaporados sobre condições definidas, bem como o "ponto final de ebulição" que é a temperatura máxima observada durante a destilação e a porcentagem do resíduo da destilação. Convém lembrar que o "porcento evaporado" é a soma do "porcento recuperado" e do "porcento perdido".

Estas características da destilação, juntamente com a pressão de vapor e a relação vapor/líquido (V/L), definem e controlam a partida do motor, seu aquecimento, aceleração, tendência ao tamponamento e diluição do óleo do cárter e, em parte, a economia de combustível. Elas controlam, ainda, a tendência a provocar o congelamento no carburador, fenômeno que ocorre a baixas temperaturas em determinadas condições de umidade. 


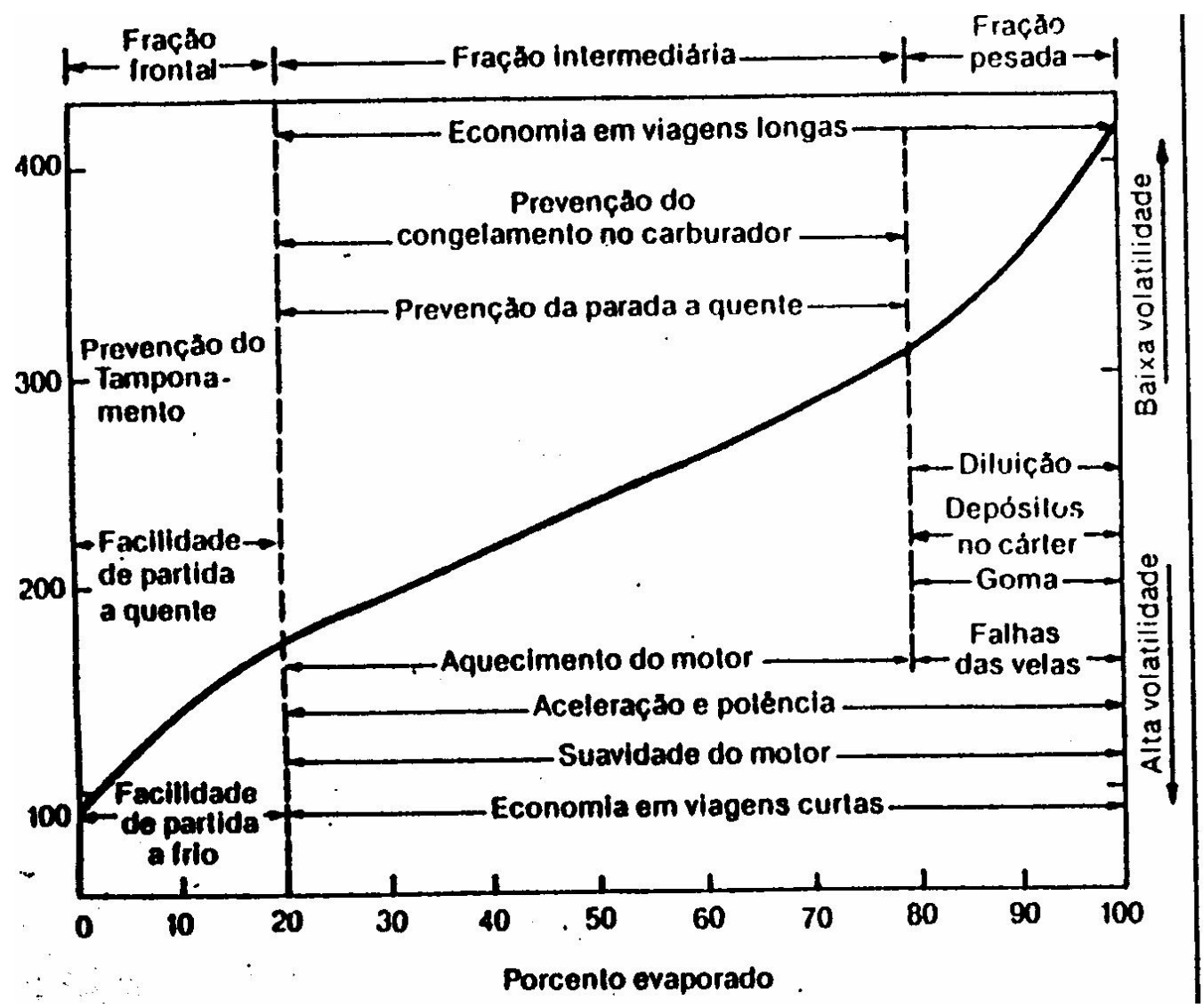

Figura 5 - Curva de destilação de gasolinas

A temperatura de evaporação dos $10 \%$ deve ser suficientemente baixa para assegurar uma partida fácil sob condições normais de temperatura ambiente.

Geralmente, a temperatura do ponto de $10 \%$ de evaporado deve ser mais baixa no inverno do que no verão. Da volatilidade dos primeiros $10 \%$ vai depender uma vaporização adequada do produto, a fim de que o motor frio entre em pleno funcionamento com menor número de rotações possível, favorecendo, desse modo, uma partida fácil e rápida. Entretanto, um ponto de 10\% demasiado baixo pode contribuir para o congelamento no carburador e ocasionar o fenômeno do tamponamento (vapor-lock). Quando duas gasolinas possuem a mesma pressão de vapor, aquela que tem um ponto $10 \%$ da destilação mais baixo, usualmente apresenta maior tendência ao tamponamento. 
O excesso de frações leves em uma gasolina favorece a interrupção do fluxo líquido ou o tornam descontínuo, podendo provocar a parada do motor ou as falhas conhecidas como "engasgue". Uma volatilidade exagerada, também, aumenta as perdas por evaporação durante o armazenamento e manipulação do produto. Por outro lado, quando a porcentagem de frações leves de uma gasolina é baixa, a partida do motor em tempo frio será mais difícil.

O "ponto $50 \%$ " da curva de destilação da gasolina indica sua capacidade de suprir uma mistura adequada de combustível durante o período de aquecimento, particularmente durante as acelerações. Quanto mais baixa a temperatura do "ponto 50\%", mais rapidamente o motor se aquecerá; entretanto, também aumentará a tendência ao congelamento no carburador, com a conseqüente possível paralisação do motor. As características de aquecimento rápido são desejáveis tanto para um bom desempenho do veículo, como para evitar o desperdício do combustível que ocorre enquanto o afogador está em operação. Em resumo, as características de aquecimento e aceleração dependem das frações intermediárias controladas pela temperatura dos $50 \%$ evaporados, que nas gasolinas atuais, se situa em torno dos $100^{\circ} \mathrm{C}$.

As temperaturas correspondente aos "90\% evaporado" e ao "ponto final e ebulição", assim como a porcentagem de resíduos indicam a quantidade de componentes da gasolina que possuem ponto de ebulição relativamente elevado.

Com o motor trabalhando na temperatura normal de operação, estes componentes contribuem para uma economia de combustível, mas, por outro lado, eles têm tendência a causar uma distribuição deficiente da mistura no coletor de admissão, bem como a propiciar a diluição do óleo lubrificante no cárter. A diluição do óleo no cárter e a lavagem do óleo lubrificante nas paredes dos cilindros ocorrem sempre que a gasolina os atinge em forma líquida e tem oportunidade de fluir para o carter, passando pelos anéis de seguimento.

Além dos inconvenientes citados, uma temperatura muito alta correspondente à fração de $90 \%$ evaporados, provocará depósitos excessivos na câmara de combustão, formação de vernizes e borra no motor. 


\subsection{4 Índice de octano}

A qualidade antidetonante de uma gasolina automotiva é de importância fundamental. Se esse poder antidetonante é baixo ocorre a detonação. $O$ índice de octano de uma gasolina é uma medida da sua qualidade antidetonante ou capacidade de resistir à detonação. Ele é determinado em um motor padrão que consiste, essencialmente, de um motor monocilíndrico, com taxa de compressão variável e que foi desenvolvido pelo Cooperative Fuel Research Committee CFR.

A eficiência e potência de um motor a gasolina dependem das suas características. O desenho da câmara de combustão, a mistura combustível, o avanço da ignição, a taxa de compressão, a qualidade da centelha, o tipo de válvulas, entre outros, têm influencia sobre a potência obtida durante a fase de expansão ou potência.

A detonação é um fenômeno de combustão anormal que depende de complexos processos físicos e químicos estreitamente interligados com o projeto do motor e as condições de operação. Não se pode caracterizar, completamente, o desempenho antidetonante de uma gasolina por intermédio de um ensaio simples.

Este desempenho está intimamente relacionado ao motor onde a gasolina é usada e às condições de operação. Esse relacionamento varia de um tipo de motor para outro e pode mesmo ser diferente para motores de uma mesma marca e tipo vindos de uma mesma linha de fabricação, devido a variações normais em uma produção em série.

$\mathrm{Na}$ combustão normal, a mistura combustível/ar em cada cilindro do motor deve queimar suave e uniformemente em seguida à ignição feita pela vela. Mas, às vezes, enquanto a frente de chama varre a câmara de combustão, a porção ainda não queimada de combustível (gás residual) sofre tal aquecimento e compressão que não resiste, sofrendo uma auto-ignição e detonando violentamente. O pistão, em vez de ser empurrado para baixo de modo uniforme na fase de potência, sofre uma pancada seca instantânea, à qual ele não pode 
responder por estar ligado ao eixo e manivela, que por sua vez está ligado a outros pistões em fases diferentes do ciclo do motor, na velocidade mantida no momento. A súbita liberação de energia da detonação na área de gás residual provoca flutuações de pressão de elevada freqüência através da câmara de combustão, que são registradas pelo ouvido como um ruído metálico forte chamado "detonação" ou "batida de pino". A energia do combustível que poderia ser convertida em trabalho útil é dissipada sob a forma de ondas de pressão e aumento de calor radiante para as peças circundantes do motor e para o fluido de refrigeração. Além de produzir um som indesejável e desperdiçar energia do combustível, a detonação prolongada superaquece as válvulas, velas e pistões, o que não somente encurta sua vida, mas também, causa a pré-ignição danosa para o motor.

Acredita-se que a detonação seja o resultado final das reações químicas que começam na mistura combustível/ar, praticamente logo depois dela ser admitida no cilindro. À medida que a temperatura da mistura é progressivamente elevada pelas paredes quentes do cilindro - pela compressão antes da fase de potência e pelo aquecimento adicional pelos gases que queimam após a ignição dada pela vela - alguns dos hidrocarbonetos do combustível sofrem uma série de reações de oxidação e craqueamento, convertendo-se em compostos instáveis, suscetíveis à auto-ignição e detonação instantânea. Em resumo, a presença ou ausência de detonação em um motor depende do resultado de uma corrida entre a frente de chama que avança e certas reações de pré-combustão que ocorrem no gás residual.

A estrutura química dos hidrocarbonetos do combustível tem enorme influência na tendência a causar detonação. As parafinas de cadeia linear têm menor resistência à detonação do que as parafinas de cadeia ramificada, olefinas e hidrocarbonetos cíclicos. Os naftênicos (cíclicos saturados) têm maior tendência à detonação do que os aromáticos (cíclicos insaturados).

O poder antidetonante de uma gasolina dependerá, fundamentalmente, e sua composição química. Assim, uma gasolina de destilação direta, rica em hidrocarbonetos de cadeia normal e longa (parafínicos) é, em geral, a que possui 
maior tendência à detonação, apresentando baixos valores para o índice de octano.

Contrariamente, gasolinas provenientes de reforma catalítica (contendo alto teor de aromáticos e isoparafinas), e de craqueamento catalítico ou térmico (contendo elevado teor de olefinas), possuem baixa tendência à detonação e altos valores de índice de octano.

Define-se índice de octano no combustível como sendo a porcentagem, por volume, de isooctano (2,2,4 - trimetilpentano) que se mistura com heptano normal para se obter a mesma intensidade de detonação que a do combustível.

Por convenção, ao isooctano foi dado o valor cem e ao heptano normal, o valor zero, devido ao seu baixo poder antidetonante, (1) A escala de octanagem foi criada pelo Dr. Graham Edgar, da Ethyl Corporation, em 1926, e possibilitava a avaliação de combustíveis com índices de octano entre zero e cem. Com o desenvolvimento de novos processos de refino e uso de aditivos químicos para aumentar a octanagem, mais tarde a escala foi ampliada para permitir testar combustíveis com índice de octano maior que cem.

Para isto, usam-se combustíveis de referência consistindo de isoctano mais quantidades conhecidas de chumbo tetraetila (atualmente, a adição de CTE à gasolina está proibida). Assim, o poder antidetonante de uma gasolina possuindo a mesma resistência à detonação que o 2,2,4 - trimetilpentano mais $1,5 \mathrm{ml}$ de chumbo tetraetila é expresso como " $100+1,5$ ".

Existem vários métodos para determinar as características antidetonantes das gasolinas. Os métodos de laboratório usam motores CFR monocilíndricos, mas o desempenho nos motores multicilíndricos em veículos é determinado em estrada, com aparelhagem especial, obtendo-se o chamado "índice de octano em estrada" (Research Octane Number - RON). Também são usados dinamômetros de chassis, que reproduzem as condições da estrada em laboratório.

A ASTM padronizou vários métodos para determinação do poder antidetonante de combustíveis. No Brasil, o método especificado é o "Motor"(MON) usando-se a norma MB-457, correspondente ao ASTM D2700. 
Os valores mínimos, constantes do Regulamento Técnico ANP № 5/2001 das PAN 309/01, estão expressos em termos de índices antidetonantes(IAD) que são, respectivamente, iguais a 91 no mínimo e 87 , em média, para as gasolinas CPREMIUM e C-comum. Como já foi mencionado o IAD é igual á média aritmética dos valores de MON e RON. O Quadro 5 fornece um resumo dos métodos ASTM.

Quadro 5 - Métodos ASTM para determinação do poder antidetonante, (1)

\begin{tabular}{|ll|}
\hline ASTM no & Características antidetonantes de \\
D 2623-68 GLP- & Método Motor(MON) \\
D 2699-70 & Combustíveis automotivos Método Pesquisa(RON) \\
D 2670-70 & $\begin{array}{l}\text { Comb.automotivos e de aviação - Método Motor } \\
\text { D 2722-71 }\end{array}$ \\
& $\begin{array}{l}\text { Comb.automotivos - Método Pesquisa - Técnica da taxa de } \\
\text { compressão }\end{array}$ \\
D 2723-71 & Comb.automotivos - Método Motor - Técnica da taxa de \\
D 2885-70 T & $\begin{array}{l}\text { Analisadores de linha - Método Pesquisa e Motor } \\
\text { D 2886-70 T }\end{array}$ \\
D 909-67 & Comb.automotivos - Índice de octano de Distribuição - DON \\
D 61613-65 & Comb.diesel. Número de cetano \\
\hline
\end{tabular}

Nos Estados Unidos e na maioria dos demais países, o método "pesquisa" é o mais usado; entretanto, normalmente, são determinados os dois valores "Motor" e "Pesquisa".

Os dois métodos diferem nas condições operacionais, sendo o método "Motor" mais severo do que "Pesquisa". Sendo mais severo, dará resultados mais 
baixos do que o segundo. A diferença entre os dois resultados chama-se "sensibilidade"(S): S = I.O.P. - I.O.M.

A sensibilidade depende da natureza do petróleo e do tipo do processo de refinação, ou seja, dos tipos de hidrocarbonetos presentes. As parafinas têm pouca ou nenhuma sensibilidade. As olefinas e aromáticos são bastante sensíveis, dando assim uma sensibilidade apreciável às gasolinas de craqueamento e reforma. Os combustíveis de referência, por definição, têm o mesmo índice de octano para os dois métodos. De um modo geral, quando dois combustíveis possuem o mesmo índice de octano "Pesquisa", aquele que tem a menor sensibilidade terá o melhor desempenho antidetonante na estrada.

Até o momento, não existe um modo totalmente satisfatório de correlacionar os resultados obtidos nos métodos de laboratório "Motor" e "Pesquisa", com os obtidos em operação na estrada para todos os tipos de veículos.

A ASTM passou a usar uma correlação aproximada à qual chamou de "Índice antidetonante" que é definida em termos dos resultados obtidos dos métodos "Motor" e "Pesquisa", assim: Ind. antidetonante $=(R O N+M O N) / 2$. Este índice é o que aparece na nova especificação norte-americana para gasolinas automotivas.

A especificação brasileira usa o índice de octano "Motor" determinado no motor CFR. Assim, para não haver confusão, deve-se lembrar que o índice de octano Motor no Brasil, corresponde ao número de octano "Motor" norteamericano (MON- motor octane number) e o índice de octano "Pesquisa" do Brasil é o número de octano Pesquisa norte-americano ( $R O N$ - Research octane number). A Quadro 6, a seguir, mostra as principais condições de operação nos métodos "Motor" e "Pesquisa". 
Quadro 6 - Condições de operação nos motores CFR, (1)

\begin{tabular}{|c|c|c|}
\hline & Método Motor & Método Pesquisa \\
\hline Velocidade do Motor & $900 \pm 9 \mathrm{rpm}$ & $600 \pm 6 \mathrm{rpm}$ \\
\hline Avanço de centelha & $\begin{array}{l}\text { Varia automaticamente } \\
\text { com a taxa de } \\
\text { compressão de } 14^{\circ}-26^{\circ} \\
\text { antes do ponto morto } \\
\text { superior }\end{array}$ & $\begin{array}{l}\text { Fixo em } 13^{\circ} \text { antes do } \\
\text { ponto morto superior }\end{array}$ \\
\hline Intensidade de batida & \multicolumn{2}{|c|}{$\begin{array}{c}\text { Aquela dada pela taxa de compressão especificada } \\
\text { para o índice de octano da amostra de acordo com } \\
\text { a tabela provida pelo método }\end{array}$} \\
\hline Temperatura da mistura & $149 \pm 1,1^{\circ} \mathrm{C}$ & Não controlada \\
\hline $\begin{array}{l}\text { Temperatura do ar de } \\
\text { admissão }\end{array}$ & $38 \pm 2,8^{\circ} \mathrm{C}$ & $\begin{array}{c}\text { Variável com a pressão } \\
\text { barométrica }\end{array}$ \\
\hline $\begin{array}{l}\text { Umidade do ar de } \\
\text { admissão }\end{array}$ & $\begin{array}{c}25 \text { a } 50 \text { grãos de água } \\
\text { por libra de ar seco }\end{array}$ & $\begin{array}{c}25 \text { a } 50 \text { grãos de água } \\
\text { por libra de ar seco }\end{array}$ \\
\hline Ajuste do carburador & \multicolumn{2}{|c|}{ Batida máxima } \\
\hline $\begin{array}{l}\text { Temperatura do fluido } \\
\text { refrigerante }\end{array}$ & \multicolumn{2}{|c|}{$100 \pm 1,5^{\circ} \mathrm{C}$ com tolerância de $\pm 0,5^{\circ} \mathrm{C}$} \\
\hline Pressão do óleo & \multicolumn{2}{|c|}{15 a 30 psi com o motor em operação } \\
\hline Viscosidade do óleo & \multicolumn{2}{|c|}{ SAE 30} \\
\hline Temperatura do óleo & \multicolumn{2}{|c|}{$57 \pm 8,5^{\circ} \mathrm{C}$} \\
\hline
\end{tabular}

\subsubsection{Pressão de vapor}

A pressão de vapor de um líquido volátil é a pressão exercida pelos vapores dos mesmos em um determinado espaço, ou em outras palavras, é a força por unidade de área exercida sobre as paredes de um recipiente fechado, pela porção vaporizada do líquido nele contido. No caso da gasolina, as condições do ensaio devem ser cuidadosamente estabelecidas, uma vez que a pressão do vapor varia 
com a temperatura, com a quantidade de ar dissolvido e com a relação entre vapor e líquido existente no recipiente.

A pressão de vapor Reid (PVR) da gasolina é aquela obtida a $37,8^{\circ} \mathrm{C}$ $\left(100^{\circ} \mathrm{F}\right)$. A PVR é expressa em termos de pressão absoluta, em Kgf/cm2. Para as gasolinas, a pressão de vapor depende particularmente das concentrações relativas de hidrocarbonetos que têm pontos de ebulição abaixo de $37,8^{\circ} \mathrm{C}$.

Considerando que a composição do líquido varia à medida que os componentes mais voláteis se vaporizam, depreende-se que a pressão de vapor do produto variará com o volume de espaço livre no aparelho.

A amostragem e o manuseio da amostra devem ser feitos com cuidados especiais no caso do ensaio de pressão de vapor, porque, senão, os resultados serão mais baixos, devido à evaporação das frações mais leves.

A pressão de vapor Reid tem grande importância em uma especificação de gasolina. É importante nas perdas por evaporação, no armazenamento, nos transportes e no manuseio. Pressões de vapor elevadas e temperaturas baixas do ponto de $10 \%$ da curva de destilação levam a facilidade de partida do motor; entretanto, por outro lado, aumentam a tendência ao tamponamento pelo vapor de combustível.

\subsubsection{Aditivos}

Os aditivos são produtos químicos solúveis na gasolina que são misturados para realçar determinadas características de desempenho ou para fornecer as características não inerentes na gasolina.

Sendo estes: antioxidantes, anticorrosivos, desativadores de metais, demulsificadores, compostos antidetonantes, anticongelamento, corantes, detergentes/dispersantes e drag reducers (GUIBET, 1999). Na Tabela 5 tem-se os principais aditivos, suas funções e seus respectivos compostos. 
Tabela 5 - Principais aditivos, suas funções e seus respectivos compostos.

\begin{tabular}{cc}
\hline \hline Aditivos & Composições \\
\hline Antioxidantes & Aminas aromáticas e fenóis \\
Anticorrosivos & Ácidos carboxílicos e carboxilatos \\
Desativadores de metais & Agentes quelantes \\
Demulsificadores & Derivados de poliglicóis \\
Compostos antidetonantes & Metilciclopentadienil Manganês \\
& Tricarbonila (MMT) \\
Anticongelamento & Surfactantes, álcoois e glicóis \\
Corantes & Ácidos carboxílicos/Carboxilatos \\
Detergente/dispersante & Aminas e imidas \\
Drag reducers & Polímeros de alta massa molecular \\
\hline \hline
\end{tabular}

Os aditivos para gasolina complementam seu processamento na refinaria e são usados para reforçar ou propiciar várias características de melhor desempenho, objetivando a operação satisfatória dos motores. O Quadro 7, a seguir, publicação da SAE (SAE J312B) fornece um resumo dos principais tipos comerciais de aditivos, sua função e tipo (HEYWOOD, 1988).

Como visto a gasolina automotiva é produzida de modo a atender requisitos definidos de qualidade. Tais requisitos visam garantir que o produto apresente condições de atender a todas as exigências dos motores e permitir que a emissão de poluentes seja mantida em níveis aceitáveis.

As características de qualidade da gasolina e seus valores limites são aqueles que constam no quadro de especificações definido pela ANP. Os limites ali fixados são plenamente atendidos por toda gasolina produzida pela Petrobrás. 
Quadro 7 - Aditivos comerciais para gasolina, função e tipo.

\begin{tabular}{|c|c|}
\hline Classe ou função & Tipo comum do aditivo \\
\hline $\begin{array}{l}\text { 1-Compostos antidetonantes - para } \\
\text { melhorar o índice de octano Pesquisa, } \\
\text { Motor e de estrada }\end{array}$ & $\begin{array}{l}\text { Chumbo alquilas, tais como chumbo tetraetila, } \\
\text { chumbo tetrametila e suas misturas físicas e de } \\
\text { reação (não mais utilizados). } \\
\text { Compostos de organomanganês, tais como } \\
\text { etilciclopentadienilmanganês-tricarbonila, } \\
\text { éteres e alcoóis }\end{array}$ \\
\hline $\begin{array}{l}2 \text { - Modificadores de depósitos da } \\
\text { combustão- para minimizar a ignição } \\
\text { superficial, o rumble, a pré-ignição e as } \\
\text { falhas nas velas. }\end{array}$ & $\begin{array}{l}\text { Compostos orgânicos ou organometálicos, } \\
\text { usualmente contendo fósforo. }\end{array}$ \\
\hline $\begin{array}{l}3 \text { - Antioxidantes - para minimizar a } \\
\text { oxidação e formação de goma na gasolina } \\
\text { e para melhorar as características de } \\
\text { manuseio e armazenamento }\end{array}$ & $\begin{array}{l}\text { Composto da fenilenodiamina, fenóis, e } \\
\text { aminofenóis. }\end{array}$ \\
\hline $\begin{array}{l}4 \text { - Desativadores de metal - para } \\
\text { desativar traços de cobre e outros íons } \\
\text { metálicos que são poderosos catalisadores } \\
\text { de oxidação. }\end{array}$ & Compostos de diaminas e aminofenóis. \\
\hline $\begin{array}{l}5 \text { - Inibidores de corrosão ou ferrugem - } \\
\text { para minimizar a corrosão e a ferrugem } \\
\text { no sistema de combustível e nas } \\
\text { facilidades de manuseio e } \\
\text { armazenamento }\end{array}$ & $\begin{array}{l}\text { Derivados de ácidos carboxílicos, sulfônicos ou } \\
\text { fosfórico, muitos dos quais possuem } \\
\text { propriedades tensoativas. }\end{array}$ \\
\hline $\begin{array}{l}6 \text { - Anticongelantes para o carburador - } \\
\text { para minimizar a parada do motor devido } \\
\text { ao acumulo de gelo na borboleta do } \\
\text { acelerador }\end{array}$ & $\begin{array}{l}\text { Derivados de ácidos carboxílicos, sulfônicos ou } \\
\text { fosfórico, muitos possuindo propriedades } \\
\text { tensoativas. Redutores do ponto de } \\
\text { congelamento, tais como os álcoois e glicóis. }\end{array}$ \\
\hline $\begin{array}{l}7 \text { - Detergentes para a gasolina - para } \\
\text { remover e/ou minimizar o acumulo de } \\
\text { depósitos na seção da borboleta do } \\
\text { carburador, que afetam adversamente as } \\
\text { características de medição }\end{array}$ & $\begin{array}{l}\text { Aminas e derivados de ácidos carboxílicos, } \\
\text { sulfônicos e fosfóricos, tendo propriedades } \\
\text { tensoativas, alguns dos quais são polímeros }\end{array}$ \\
\hline $\begin{array}{l}\text { 8- Dispersantes para a gasolina - para } \\
\text { ampliar a vida da válvula PCV } \\
\text { (ventilação positiva do cárter), reduzir a } \\
\text { borra do motor, e remover e/ou } \\
\text { minimizar o acumulo de depósitos no } \\
\text { carburador, coletor de admissão, e lado } \\
\text { inferior das válvulas de admissão. }\end{array}$ & $\begin{array}{l}\text { Aminas e polímeros sintéticos de baixo peso } \\
\text { molecular. Frações específicas de óleos } \\
\text { especiais. }\end{array}$ \\
\hline $\begin{array}{l}9 \text { - Corantes - para identificar misturas } \\
\text { de gasolinas }\end{array}$ & Corantes sólidos e líquidos solúveis em óleo \\
\hline
\end{tabular}


Pode-se destacar resumidamente que as principais características na especificação da gasolina são: aspecto, cor, teor de enxofre, destilação, pressão de vapor (RVP Reid Vapor Pressure) e número de octano (octanagem). A seguir será abordada cada uma delas, individualmente, indicando seus significados. O aspecto é um teste que dá uma indicação visual da qualidade e da possível contaminação do produto.

A gasolina deve apresentar-se límpida e isenta de materiais em suspensão como água, poeira, fuligem, entre outros. Estes, quando presentes, podem reduzir a vida útil dos filtros de combustível dos veículos e prejudicar o funcionamento dos motores. O teste é feito observando-se, contra a luz natural, uma amostra de 0,9 litro do produto contida em recipiente de vidro transparente e com capacidade total de 1 litro.

A cor indica a tonalidade característica do produto. No caso da gasolina Tipo A e Tipo C, sem aditivo, a cor pode variar de incolor a amarelo. Quando a gasolina é aditivada, ela recebe um corante para diferenciá-la das demais, podendo apresentar qualquer cor, exceto azul (reservada para a gasolina de aviação) e rosa (reservada para a mistura formada por metanol, etanol e gasolina - MEG). A gasolina aditivada comercializada pela Petrobrás Distribuidora (BR) apresenta cor verde. Alterações na cor da gasolina podem ocorrer devido à presença de contaminantes ou oxidação de compostos instáveis (olefinas e compostos nitrogenados).

O teor de enxofre indica a concentração total dos compostos, mercaptanas, presentes na gasolina. O enxofre é um elemento indesejável em qualquer combustível devido à ação corrosiva de seus compostos e à formação de gases tóxicos como $\mathrm{SO}_{2}$ e $\mathrm{SO}_{3}$, que ocorre durante a combustão do produto. Nos veículos dotados de catalisador, quando a carga de material catalítico não é adequada ou quando não está devidamente dimensionada, o enxofre pode levar à formação de $\mathrm{H}_{2} \mathrm{~S}$ que é tóxico e apresenta odor desagradável.

$A$ análise é feita incidindo raios $X$ em uma célula contendo amostra do produto. Neste teste, os átomos de enxofre absorvem energia de um comprimento 
de onda específico numa quantidade proporcional à concentração de enxofre presente na gasolina.

A destilação é um dos testes que tem como objetivo avaliar as características de volatilidade da gasolina. O teste é feito retirando-se $100 \mathrm{~mL}$ da amostra do produto que é coletado em um balão de vidro especial, que a seguir, é submetido a aquecimento para destilação em condições controladas. Com esse aquecimento, o produto se vaporiza sendo, então, condensado e recolhido em uma proveta de vidro. Após essa operação, as temperaturas anotadas são corrigidas levando-se em conta as perdas que ocorrem por evaporação de pequena parte do produto e a pressão barométrica. Esse teste é muito importante, pois há uma especificação da ANP para as temperaturas com 10, 50 e 90\% do produto destilado/evaporado, sendo estas, respectivamente, T10, T50 e T90. Os resultados da destilação indicam as frações leves, médias e pesadas, as quais além de demonstrar a composição da gasolina, qualifica o combustível quanto ao seu desempenho no veículo, principalmente na partida à frio, consumo e dirigibilidade.

Assim como o teste de destilação, a Pressão de Vapor (RVP Reid Vapor Pressure) tem como objetivo avaliar a tendência da gasolina de evaporar-se, de modo que, quanto maior é a pressão de vapor, mais facilmente a gasolina se evapora. Esse ensaio é utilizado, principalmente, para indicar as exigências que devem ser satisfeitas para o transporte e armazenamento do produto, de modo a evitar acidentes e minimizar as perdas por evaporação.

Outro aspecto importante é o número de octano ou o seu índice antidetonante $(I A D)$. A octanagem de uma gasolina indica sua resistência à detonação, em comparação com uma mistura contendo iso-octano (ao qual é creditado um número de octano igual a 100) presente em uma mistura com nheptano (número de octano igual a zero). Exemplificando, uma gasolina terá uma octanagem igual a $80 \mathrm{se}$, durante o teste, apresentar a mesma resistência à detonação apresentada por uma mistura que contém $80 \%$ em volume de isooctano e $20 \%$ em volume de $n$-heptano. 
A avaliação da octanagem da gasolina é justificada pela necessidade de garantir que o produto atenda às exigências dos motores no tempo de compressão e início da expansão (quando ocorrem aumento de pressão e de temperatura) sem entrar em auto-ignição.

\subsubsection{Resíduo no motor}

As principais causas do resíduo no motor são: a alta temperatura que leva a oxidação do óleo; combustível de má qualidade; diluição do óleo por combustível e gases de combustão; óleo de baixa qualidade (recuperado) e a não troca do óleo no motor, apenas adição para acertar o nível.

O resíduo é formado por meio de reação de oxidação e o catalisador deste processo pode também ser o calor. Acima de $50-60^{\circ} \mathrm{C}$, a cada $10^{\circ} \mathrm{C}$ de aumento na temperatura, dobra a oxidação, isto resulta na polimerização (borra) do óleo (insaturação na cadeia carbônica do óleo - peróxidos orgânicos). A Figura 6 apresenta uma micrografia óptica do resíduo no motor.

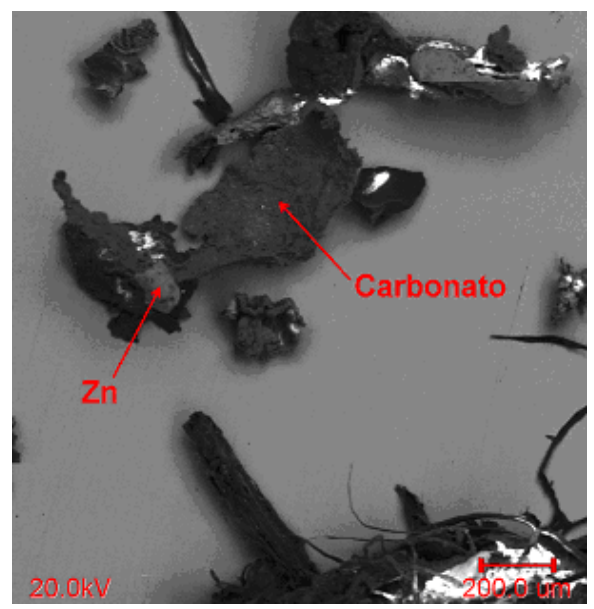

Figura 6 - Fotografia do resíduo no motor. 


\section{MATERIAIS E MÉTODOS}

Foram estudadas, pelas técnicas de espectrometria de absorção no infravermelho, espectrometria de emissão atômica, microscopia eletrônica de varredura e microanálise eletrônica com espectro de energia dispersiva (MEVEDS), respectivamente, a presença de grupos funcionais, presença de metais e não metais e caracterização da microestrutura no resíduo presente no motor automotivo à gasolina.

A presença deste resíduo prejudica a funcionabilidade do motor, sendo as

principais causas de sua formação: a alta temperatura que leva a oxidação do óleo; combustível de má qualidade; diluição do óleo por combustível e gases de combustão; óleo de baixa qualidade (recuperado) e a não troca do óleo no motor e sim, apenas adição para acertar o nível do mesmo.

Cabe ressaltar que por meio destas técnicas analíticas é possível distinguir o resíduo proveniente do óleo no motor, do resíduo oriundo de combustível de má qualidade.

Estudou-se também as relações entre as espécies presentes no resíduo com intuito de efetuar mudanças no processo, ou mesmo adicionar algum aditivo para evitar ou mesmo minimizar tal formação.

\subsection{MATERIAIS E MÉTODOS PARA CARACTERIZAÇÃO}

A caracterização do resíduo é efetuada por algumas técnicas instrumentais, sendo estas: espectrometria de absorção no infravermelho, que indica a presença de grupos funcionais; espectrometria de emissão atômica e microanálise eletrônica que caracteriza os materiais metálicos e também a microscopia eletrônica de varredura que caracteriza a microestrutura. A seguir serão descritas, resumidamente, cada uma destas técnicas. 


\subsubsection{Espectrometria de Absorção no Infravermelho}

A espectrofotometria é o processo instrumental de medição baseado nas propriedades de absorção e emissão de energia eletromagnética em alguma região do espectro eletromagnético. A porção do espectro percebida pelo olho humano (região visível) está compreendida entre comprimentos de onda de 380 $\mathrm{nm}$ e $780 \mathrm{~nm}$ e, acima desse limite, até cerca de $50.000 \mathrm{~nm}$ (faixa entre as regiões do visível e das microondas), a radiação é chamada infravermelha (IV). A região

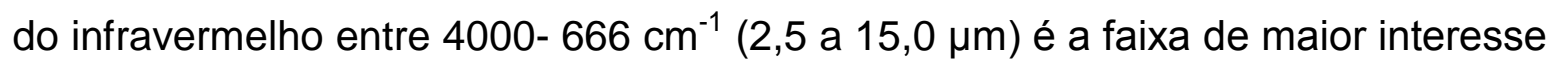
para os químicos, embora as regiões do infravermelho próximo, $14290-4000 \mathrm{~cm}^{-1}$ $(0,7$ a $2,5 \mu \mathrm{m})$ e do infravermelho distante $700-200 \mathrm{~cm}^{-1}(14,3$ a $50 \mu \mathrm{m})$ vem aumentando ultimamente. (CIENFUEGOS, 2000).

O objetivo da espectroscopia de absorção no IV é a determinação dos grupos funcionais de um dado material. Cada grupo absorve em freqüência característica de radiação na região do IV. Assim, um gráfico de intensidade de radiação versus freqüência permite caracterizar os grupos funcionais de um padrão ou de um material desconhecido. (KELLNER, 1998).

Embora o espectro no IV seja característico da molécula, como um todo, certos grupos de átomos originam bandas aproximadamente na mesma freqüência, independentemente da estrutura da molécula. É justamente a presença dessas bandas características de grupos funcionais que permitem a obtenção de informações estruturais úteis para a identificação de substâncias.

Algumas das vantagens dessa técnica são: a facilidade de preparação da amostra; a possibilidade do uso de amostras em filmes sólidos, amostras líquidas e gasosas; bem como o custo, o tamanho e a versatilidade do equipamento necessário para as análises.

O panorama da utilização da técnica tem apresentado mudanças, desde meados dos anos 80 . Além da substituição gradual dos equipamentos inicialmente empregados, denominados espectrofotômetros dispersivos, por espectrofotômetros com transformada de Fourier (FTIR), começam a desenvolverse as aplicações na região do infravermelho próximo (NIR). (SKOOG, 2002). 


\subsubsection{Espectrometria de Emissão Atômica}

Muitos elementos metálicos sob conveniente excitação emitem radiações de comprimento de onda característico. Esse fato é utilizado nos testes qualitativos de chama para os metais alcalinos e alcalino terrosos. Usando-se excitações elétricas mais poderosas em lugar da chama, pode-se estender 0 método a todos os elementos metálicos e não-metálicos. Em alguns os espectros são simples, consistindo em apenas uns poucos comprimentos de onda; enquanto que outros estão presentes centenas de comprimentos de ondas distintos e reproduzíveis. As análises quantitativas com o espectrógrafo baseiam-se na relação entre a potência da radiação emitida de determinado comprimento de onda e a quantidade do elemento correspondente na amostra, essa relação é empírica. A potência radiante é influenciada de um modo complicado por diversas variáveis, incluindo a temperatura do arco excitante e tamanho, forma e material dos eletrodos. (CIENFUEGOS, 2002).

$\mathrm{Na}$ espectrometria de emissão atômica óptica, geralmente, os atomizadores não somente convertem os componentes das amostras em átomos ou íons elementares, mas também, nesse processo, excitam uma fração dessas espécies a altos estados eletrônicos. A rápida relaxação dessas espécies excitadas é acompanhada pela produção de linhas espectrais ultravioleta e visíveis que são úteis na análise elementar qualitativa e quantitativa. Historicamente, a espectroscopia de emissão atômica baseou-se na atomização e excitação por chama, arco elétrico e centelha elétrica, e todos esses métodos continuam tendo aplicações importantes na análise de elementos metálicos. Atualmente, entretanto, fontes de plasma têm se tornado o método mais importante e largamente utilizado para a espectroscopia de emissão atômica.

As espectrometrias de emissão por plasma, arco e centelha oferecem muitas vantagens quando comparadas com as por chama e métodos de absorção eletrotérmica. Uma dessas vantagens é a baixa interferência entre elementos, que é uma conseqüência direta de suas altas temperaturas. Em segundo lugar, bons espectros de emissão são obtidos para a maioria dos elementos em um único 
conjunto de condições de excitação; como conseqüência, os espectros para vários elementos podem ser registrados simultaneamente. Essa propriedade tem particular importância para a análise multielementar de amostras de tamanho reduzido. (KELLNER, 1998).

Neste sentido, as fontes de chama são menos satisfatórias porque as condições ótimas de excitação variam muito de elemento para elemento; são necessárias temperaturas muito altas para excitação de alguns elementos e baixas temperaturas para outros; e, finalmente, a região da chama que dá origem a intensidades ótimas de linha varia de elemento para elemento. Outra vantagem da emissão atômica, principalmente de fontes de plasma é que elas permitem a determinação de baixas concentrações de elementos que tendem a formar compostos refratários (isto é, compostos como óxidos de boro, fósforo, tungstênio, urânio, zircônio e nióbio que são altamente resistentes à decomposição térmica). Além disso, as fontes de plasma permitem a determinação de não-metais, tais como cloro, bromo, iodo e enxofre.

\subsubsection{Microscopia Eletrônica de Varredura}

Durante a fase de produção ou análise de materiais, quase sempre se torna necessário analisar a sua microestrutura. Esta análise microestrutural é muito importante pois permite: entender as correlações microestrutura, defeitos, propriedades e predizer as propriedades do material quando estas correlações são estabelecidas.

As técnicas mais utilizadas para este tipo de análise são: Microscopia Óptica e Eletrônica. No caso da microscopia óptica, o contraste da imagem é resultado da diferença de refletividade da luz nas diversas regiões da microestrutura, uma vez que o sistema é constituído basicamente pela fonte de iluminação e do sistema de lentes. Para materiais que são opacos a luz visível, como é o caso dos metais, da maioria dos cerâmicos e polímeros, somente a superfície pode ser observada e a mesma precisa ser cuidadosamente preparada de maneira a revelar os detalhes da microestrutura. (KELLNER, 1998). 
Uma das limitações da microscopia óptica é o aumento máximo conseguido que fica em torno de 2000 vezes. Como conseqüência, pequenos detalhes estruturais não são possíveis de serem detectados através desta técnica. A microscopia eletrônica de varredura se apresenta como a técnica mais adequada, pois permite alcançar aumento muito superior ao da microscopia óptica. Dependendo do material pode atingir até 900000 vezes, mas para a análise de materiais normalmente o aumento é da ordem de 10000 vezes.

$\mathrm{Na}$ microscopia eletrônica de varredura os sinais de maior interesse para a formação da imagem são os elétrons secundários e os retroespalhados. À medida que o feixe de elétrons primários vai varrendo a amostra, estes sinais vão sofrendo modificações de acordo com as variações da superfície. Os elétrons secundários fornecem imagem de topografia da superfície da amostra e são os responsáveis pela obtenção das imagens de alta resolução, já os retroespalhados fornecem imagem característica de variação de composição.

O Microscópio Eletrônico de Varredura (MEV) se tornou um instrumento imprescindível nas mais diversas áreas: eletrônica, geologia, ciência e engenharia dos materiais. Em particular, o desenvolvimento de novos materiais tem exigido um número de informações bastante detalhado das características microestruturais só possível de ser observado no MEV.

O MEV tem seu potencial ainda mais desenvolvido com a adaptação na câmara da amostra de detectores de raios-X, permitindo a realização de análise química na amostra em observação. Através da captação pelos detectores e da análise dos raios- $X$ característicos emitidos pela amostra, resultado da interação dos elétrons primários com a superfície, é possível obter informações qualitativas e quantitativas da composição da amostra na região submicrométrica de incidência do feixe de elétrons. Este procedimento facilita a identificação de precipitados e mesmo de variações de composição química dentro de um grão. Atualmente quase todos os MEV são equipados com detectores de raios- $X$, sendo que devido a confiabilidade e principalmente devido a facilidade de operação, a grande maioria faz uso do detector de energia dispersiva (EDX). (MALISKA, 2006). 
O aumento máximo conseguido pelo MEV fica entre o microscópio óptico (MO) e o Microscópio Eletrônico de Transmissão (MET). A grande vantagem do MEV em relação ao microscópio óptico é sua alta resolução, na ordem de 2 a 5 $\mathrm{nm}(20$ - $50 \AA)$ - atualmente existem instrumentos com até $1 \mathrm{~nm}(10 \AA)$ - enquanto que no óptico é de $0,5 \mu \mathrm{m}$.

Comparado com o MET a grande vantagem do MEV está na facilidade de preparação das amostras. Entretanto, não é apenas esta característica que faz do MEV uma ferramenta tão importante e tão usada na análise dos materiais, a elevada profundidade de foco (imagem com aparência tridimensional) e a possibilidade de combinar a análise microestrutural com a microanálise química são fatores que em muito contribuem para o amplo uso desta técnica. A observação e análise de fratura tiveram um grande avanço com $\circ$ uso do microscópio eletrônico de varredura. (SKOOG, 2002).

A versatilidade da microscopia eletrônica de varredura e da microanálise se encontra na possibilidade de se poder captar e medir as diversas radiações provenientes das interações elétron-amostra. Estas interações podem revelar informações da natureza da amostra incluindo composição, topografia, potencial eletrostático, campo magnético local e outras propriedades da amostra. 


\section{DESENVOLVIMENTO EXPERIMENTAL}

Foram estudadas por meio de técnicas analíticas as espécies presentes no resíduo (depósito) em motor automotivo à gasolina. Estas técnicas, como descrito anteriormente são: espectrometria de absorção no infravermelho, com o intuito de verificar os grupos funcionais existentes; espectrometria de emissão atômica, visando caracterizar a presença de metais bem como não metais; e a microscopia eletrônica de varredura com o objetivo de caracterizar a microestrutura bem como microanálise eletrônica elementar.

Após a obtenção dos resultados, estudos foram efetuados com o intuito de verificar se tal resíduo é proveniente do óleo no motor, ou mesmo da gasolina de má qualidade.

Inicialmente foram obtidas amostras de resíduos (depósitos), de motor à gasolina; estas foram retiradas do cilindro do motor, da válvula de admissão e do sistema de injeção de combustível (bico injetor). A presença do resíduo, principalmente na válvula de admissão é o que causa maior incômodo para o consumidor e danos para o motor, como desgaste e durabilidade. No total foram realizadas análises em 10 motores, nas quais os resíduos foram caracterizados pelas técnicas descritas.

\subsection{PREPARO DA AMOSTRA PARA ANÁLISE POR MICROSCOPIA ELETRÔNICA DE VARREDURA \\ Para esta análise mergulhou-se o resíduo em solução de acetona P.A., com o intuito de remover a graxa ou óleo presente. Em seguida a mesma foi seca e levada para a identificação da partícula e composição do resíduo.}


4.2. PREPARO DA AMOSTRA PARA ANÁLISE POR ESPECTROFOTOMETRIA DE EMISSÃO POR PLASMA ACOPLADO INDUTIVAMENTE

Para esta análise transferiu-se o resíduo para um balão de fundo redondo de 250mL, adicionou-se $2 \mathrm{~mL}$ de $\mathrm{H}_{2} \mathrm{O}_{2} 10 \%$ em volume e $0,2 \mathrm{~mL}$ de $\mathrm{HNO}_{3}$ concentrado. O balão foi colocado numa manta de aquecimento até a solução entrar em ebulição. Após esse processo adicionaram-se alíquotas de $2 \mathrm{~mL}$ de $\mathrm{H}_{2} \mathrm{O}_{2} 10 \%$ em volume, sempre após o resfriamento para oxidar todo material orgânico até digestão total da amostra. Em seguida, transferiu-se a solução para o balão volumétrico de $100 \mathrm{~mL}$ completou-se o volume e levou-se para análise.

\subsection{PREPARO DA AMOSTRA PARA ANÁLISE POR ESPECTROFOTOMETRIA DE ABSORÇÃO NO INFRAVERMELHO COM TRANSFORMADA DE FOURIER}

Para esta análise o resíduo foi colocado sobre pastilhas de $\mathrm{KBr}$, com auxílio de uma espátula, até a obtenção de espessura fina $(2 \mathrm{~mm})$. As pastilhas obtidas foram inseridas no compartimento de leitura do espectrofotômetro de infravermelho. $\mathrm{O} \mathrm{KBr}$ foi previamente dessecado em estufa à $120^{\circ} \mathrm{C}$ até peso constante e triturado em almofariz de ágata. Posteriormente foram colocados $100 \mathrm{mg}$ de $\mathrm{KBr}$ no pastilhador seguido de compressão em prensa hidráulica com pressão de 10 toneladas por 2 minutos, para obtenção de pastilhas finas e transparentes.

\subsection{REAGENTES E EQUIPAMENTOS UTILIZADOS}

Todos os reagentes utilizados foram de grau analítico da Merck e Aldrich. Prensa hidráulica Perkin Elmer, modelo 4037. Espectrofotômetro de Infravermelho com TranSformada de Fourrier Perkin Elmer, modelo 60508. Espectrofotômetro de emissão por plasma acoplado indutivamente Varian, modelo 1275. 


\section{RESULTADOS E DISCUSSÕES}

Para identificação da partícula, bem como o composto presente, utilizou-se a técnica analítica de Microscopia Eletrônica de Varredura e o Espectro de Energia Dispersiva em algumas amostras de resíduo. Estes resultados estão representados nas Figuras 7 a 10.

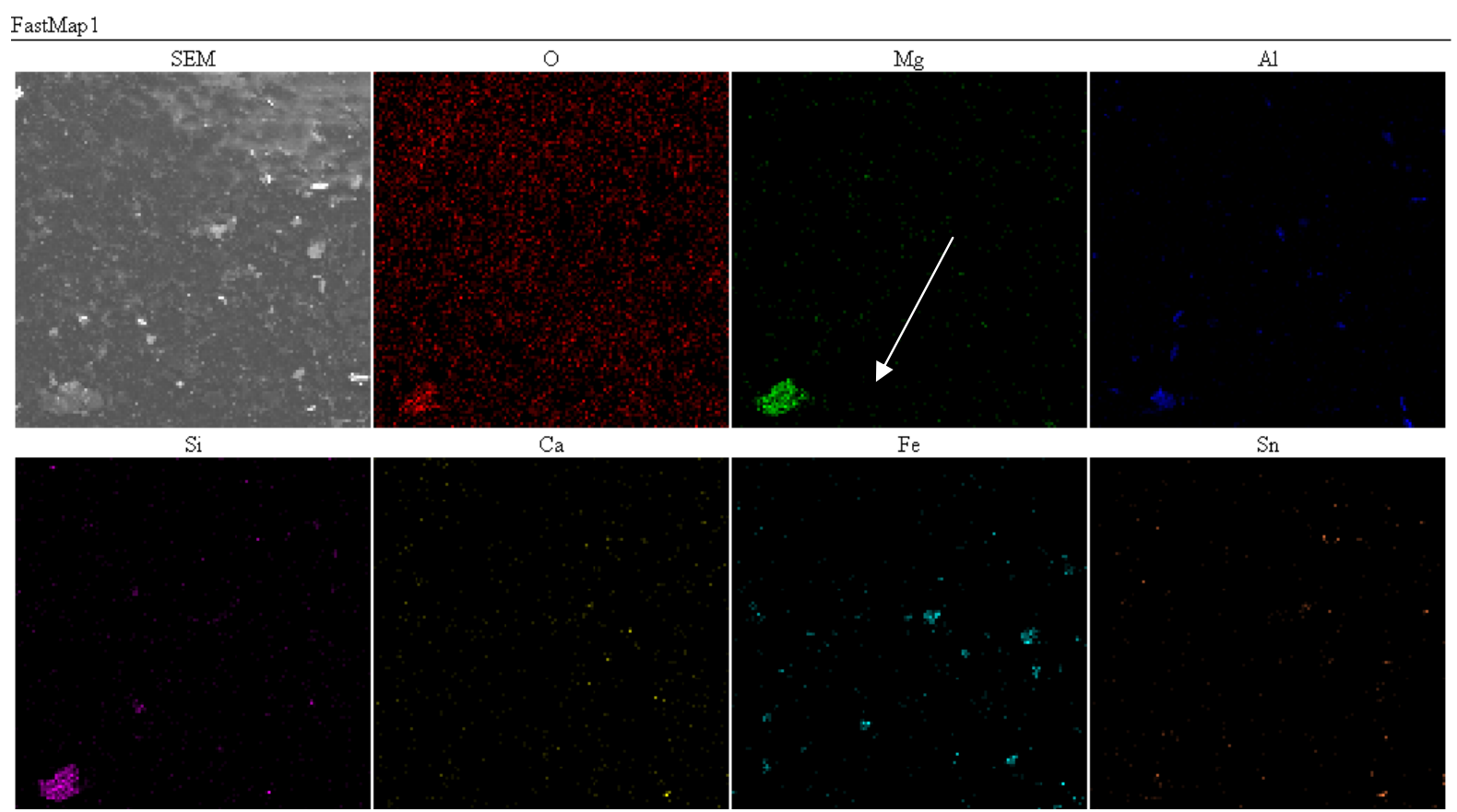


FastMap3

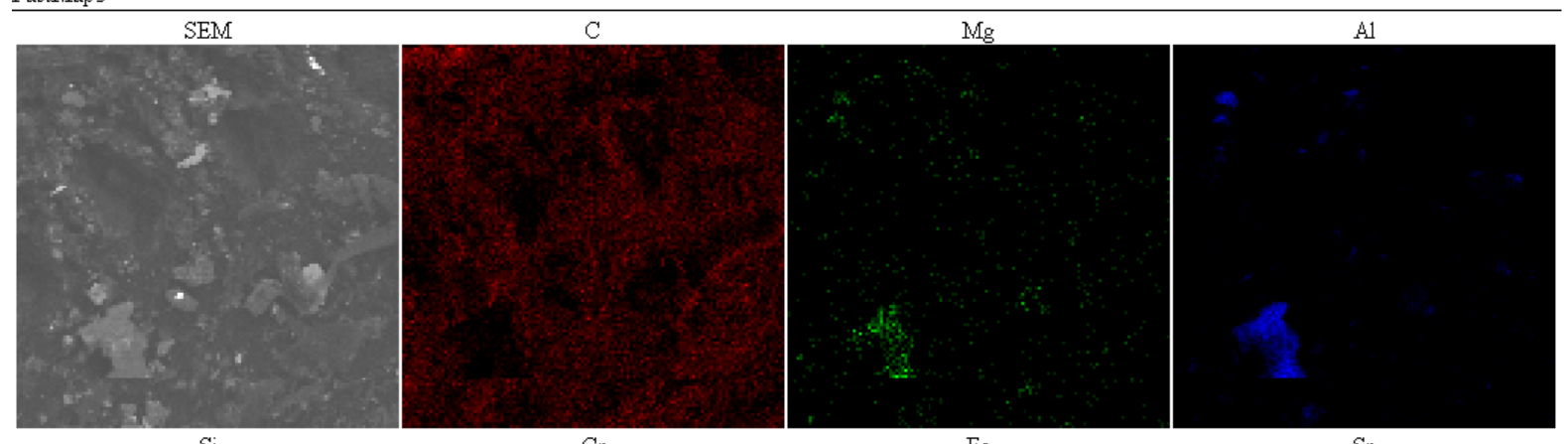

Si

$\mathrm{Cr}$

$\mathrm{Fe}$

Sn
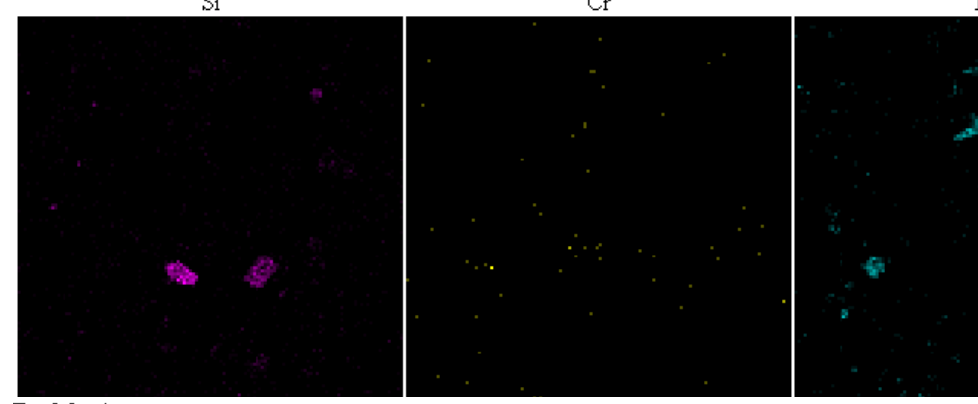

an
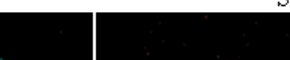

FastMap4

SEM

o

$\mathrm{Mg}$

8

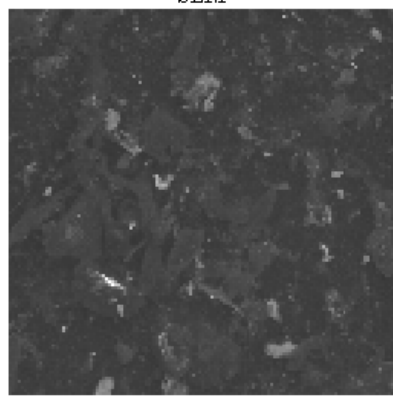

$\mathrm{Si}$

Cr

$\mathrm{Fe}$

Sn
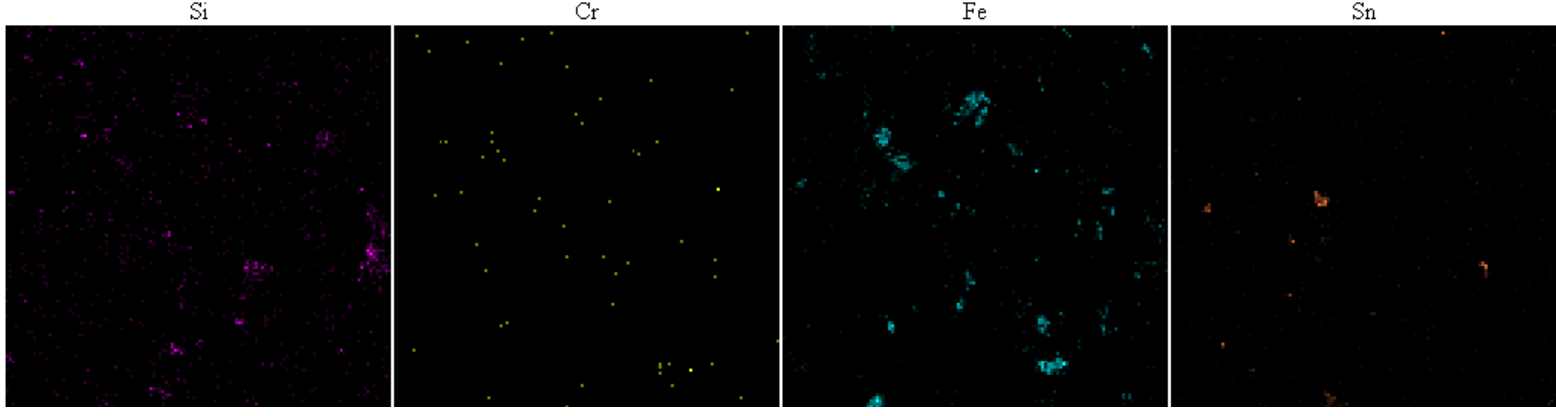
FastMap 5

SEM

0

$\mathrm{Mg}$

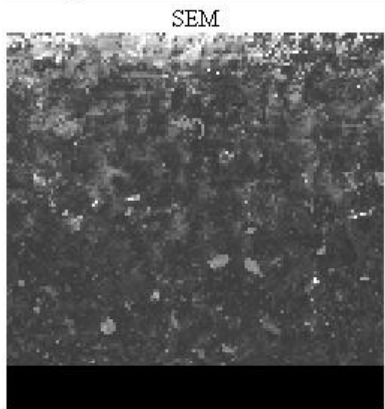

$\mathrm{Si}$

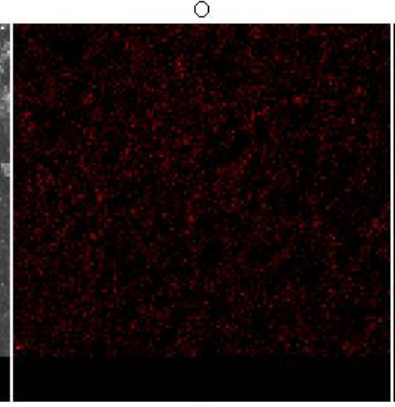

$\mathrm{Cr}$
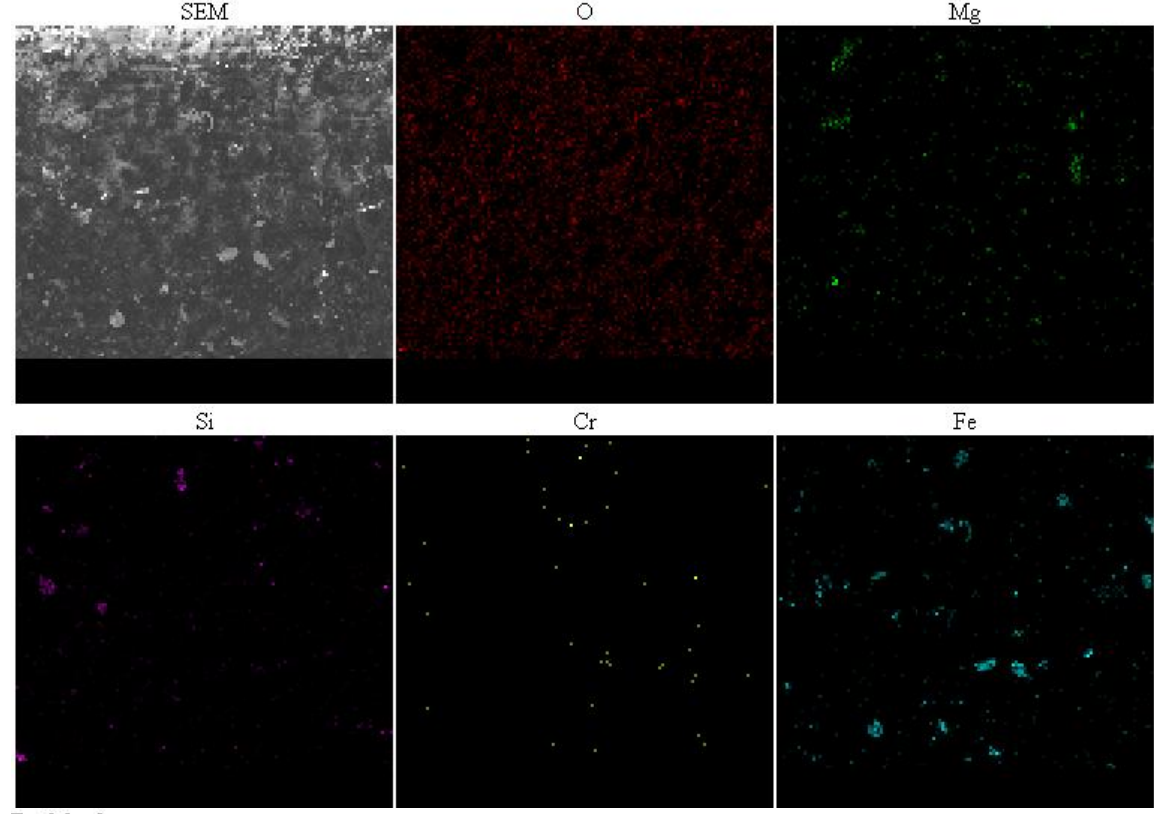

$\mathrm{Fe}$

FastMap6

SEM

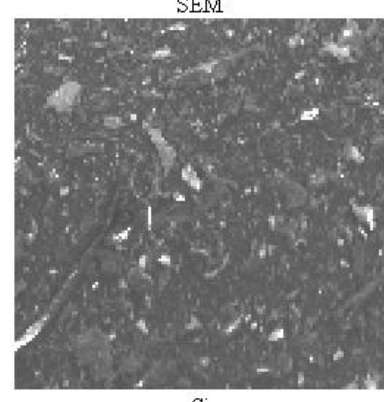

$\mathrm{Si}$

Cr

$\mathrm{Fe}$

Sn

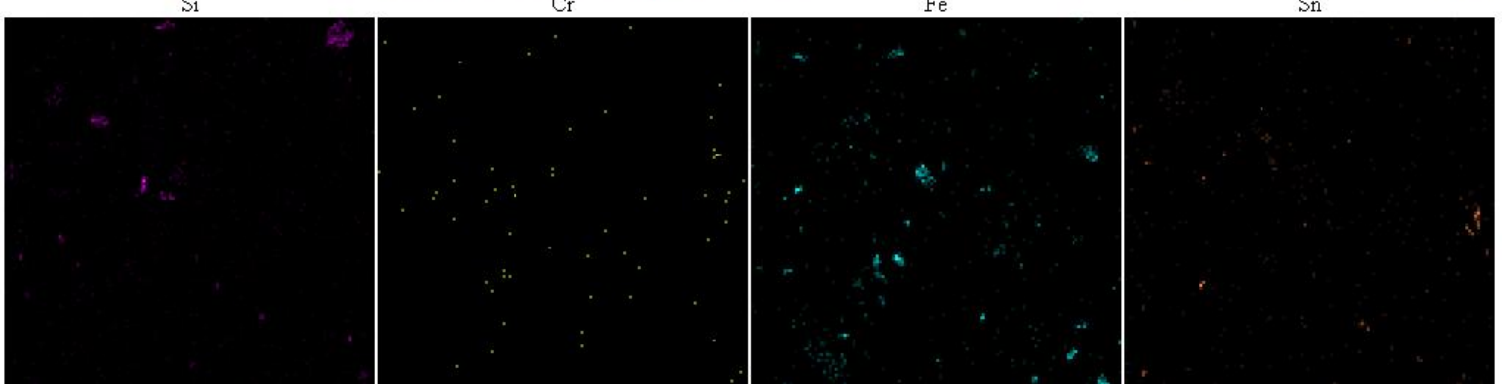




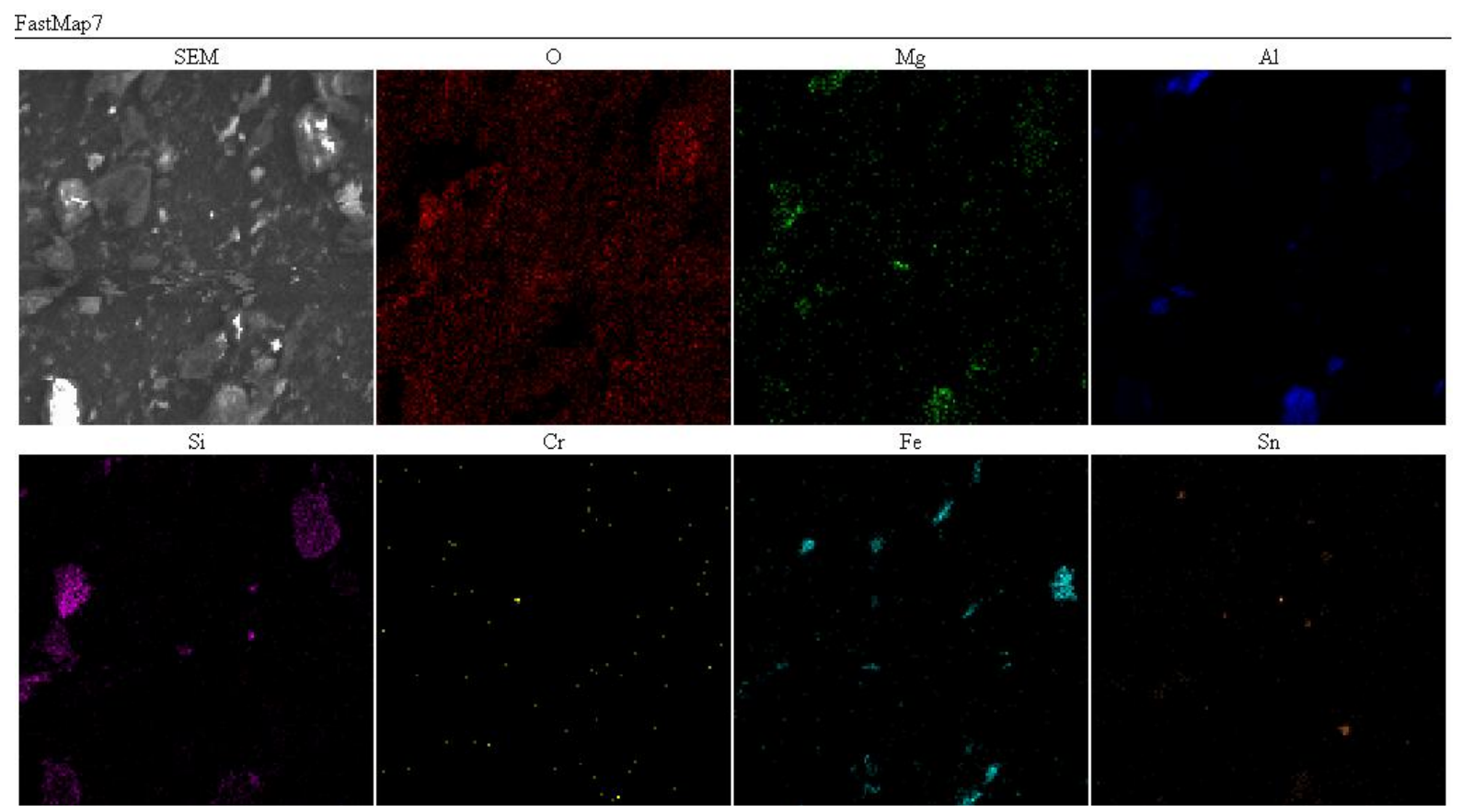

Figura 7 - Análise do resíduo por Microscopia Eletrônica de VarreduraMapeamento de Elementos por 


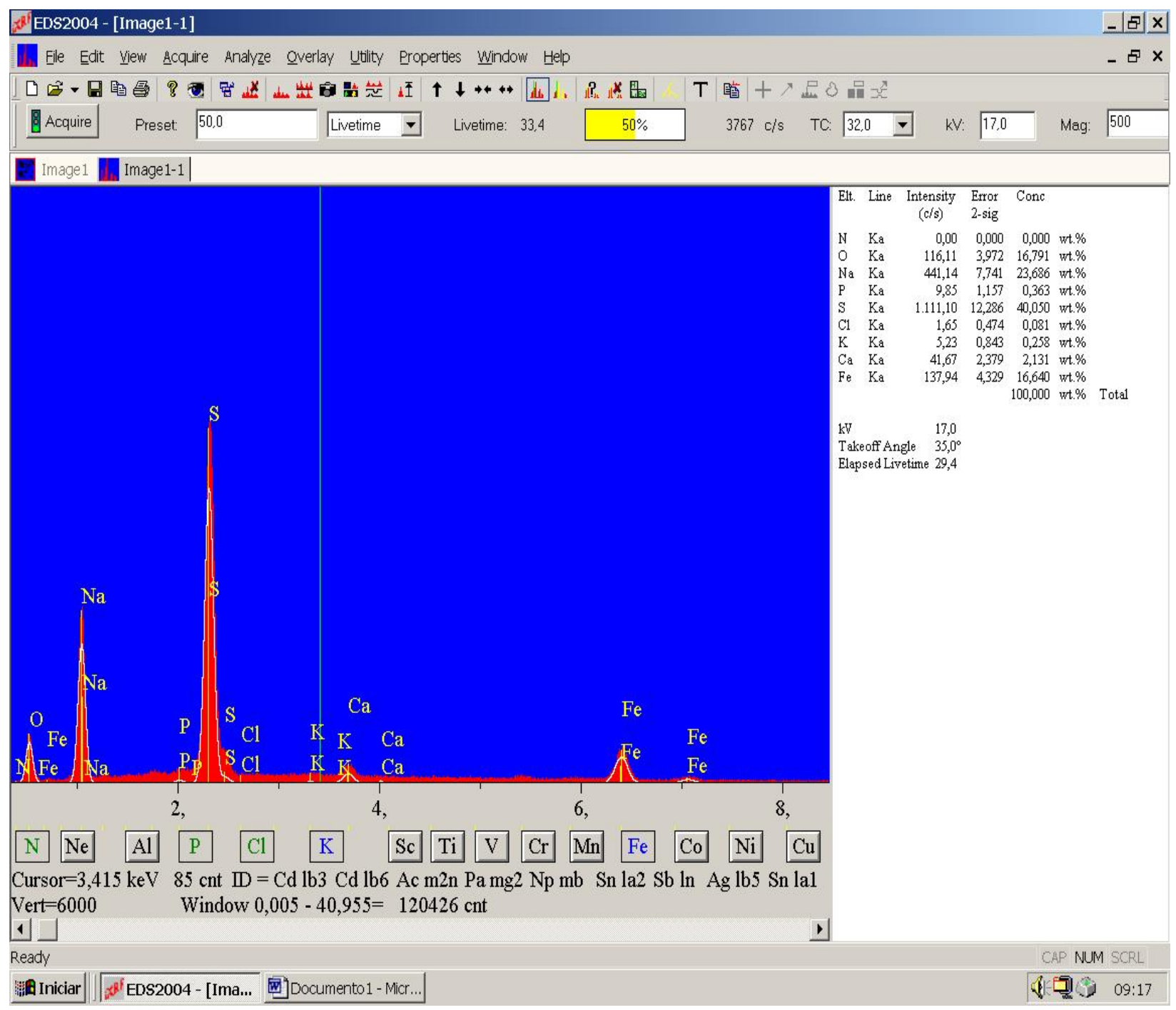

Cores.

Figura 8 - Espectro de Energia Dispersiva 

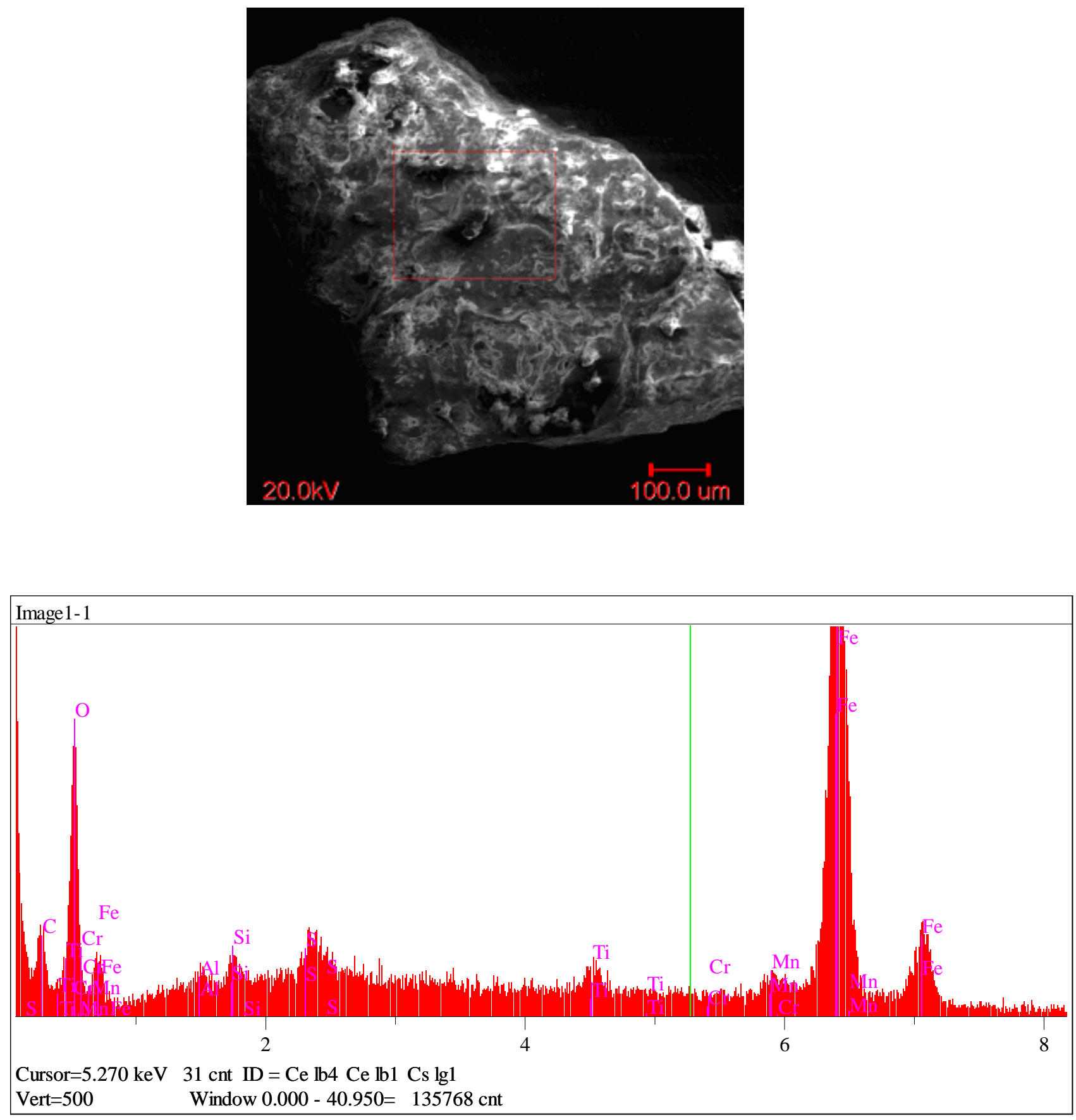

Figura 9 - Análise do resíduo por Microscopia Eletrônica de Varredura. Partícula de ferro. 

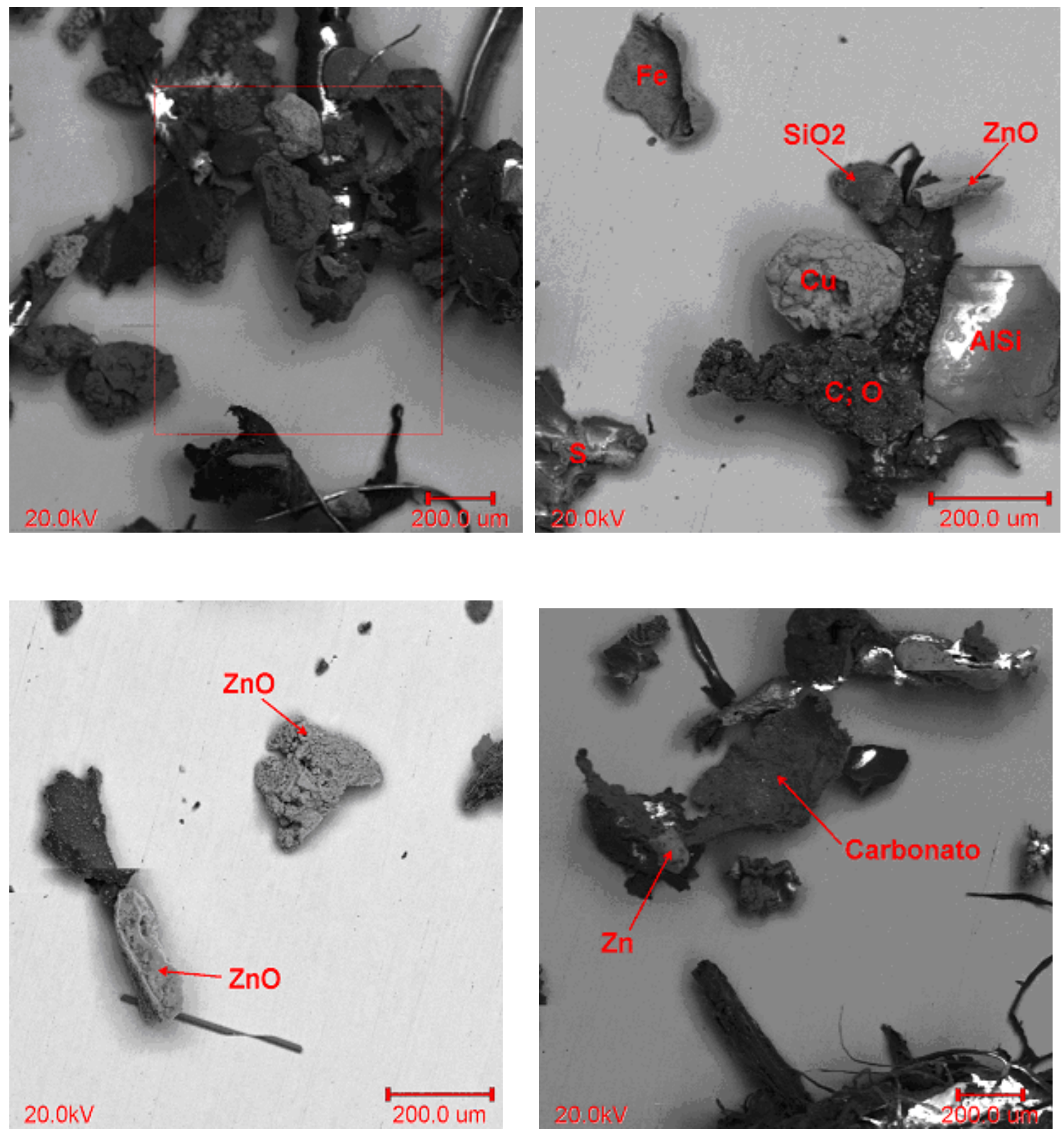

Figura 10 - Análise do resíduo por Microscopia Eletrônica de Varredura.

Como dito estas duas técnicas acopladas permitem identificar a partícula, bem como o composto presente, como, por exemplo, na Figura 9 o elemento ferro e na Figura 10 composto de carbono, enxofre, com partículas de alumínio, silício, ferro e zinco.

Pela técnica de espectrofotometria de emissão por plasma acoplado indutivamente identificou-se a presença dos elementos descritos nas Tabelas 6 a 8 . 
Tabela 6 - Elementos encontrados em 10 amostras analisadas de resíduos do cilindro do motor.

\begin{tabular}{cc}
\hline Elemento Encontrado & Porcentagem (\%) \\
$\mathrm{Al}$ & 0,04 \\
$\mathrm{Ca}$ & 0,02 \\
$\mathrm{~K}$ & 0,16 \\
$\mathrm{Mg}$ & 0,03 \\
$\mathrm{~S}$ & 0,19 \\
$\mathrm{Si}$ & 0,05 \\
$\mathrm{Zn}$ & 0,07 \\
$\mathrm{Fe}$ & 0,02 \\
$\mathrm{Cu}$ & 0,01 \\
\hline
\end{tabular}

Tabela 7 - Elementos encontrados em 10 amostras analisadas de resíduos de válvula de admissão.

\begin{tabular}{cc}
\hline Elemento Encontrado & Porcentagem (\%) \\
$\mathrm{Al}$ & 0,02 \\
$\mathrm{Ca}$ & 0,03 \\
$\mathrm{~K}$ & 0,15 \\
$\mathrm{Mg}$ & 0,02 \\
$\mathrm{Na}$ & 16,0 \\
$\mathrm{~S}$ & 0,20 \\
$\mathrm{Si}$ & 0,05 \\
$\mathrm{Zn}$ & 0,06 \\
$\mathrm{Fe}$ & 0,03 \\
$\mathrm{Cu}$ & 0,01 \\
\hline
\end{tabular}


Tabela 8 - Elementos encontrados em 10 amostras analisadas de resíduos do sistema de injeção de combustível.

\begin{tabular}{cc}
\hline Elemento Encontrado & Porcentagem (\%) \\
$\mathrm{Al}$ & 0,03 \\
$\mathrm{Ca}$ & 0,02 \\
$\mathrm{~K}$ & 0,12 \\
$\mathrm{Mg}$ & 0,03 \\
$\mathrm{Na}$ & 17,5 \\
$\mathrm{~S}$ & 0,15 \\
$\mathrm{Si}$ & 0,05 \\
$\mathrm{Zn}$ & 0,06 \\
$\mathrm{Fe}$ & 0,02 \\
$\mathrm{Cu}$ & 0,01 \\
\hline
\end{tabular}

As amostras se referem aos resíduos retirados do cilindro do motor, da válvula de admissão e do sistema de injeção de combustível (bico injetor).

A presença de sódio nos resíduos analisados provenientes da válvula de admissão, demonstram que há presença de combustível adulterado, oriundo do álcool anidro (misturado a gasolina - etanol $25 \%$ )

A presença de enxofre no resíduo mostra também a presença de óleo lubrificante de motor, em função do aditivo antidesgaste denominado ditioalquilfosfato de zinco.

Os demais elementos se encontram em porcentagem dentro dos padrões estabelecidos pela agência nacional do petróleo.

A técnica de espectrofotometria de absorção no infravermelho com transformada de Fourier para caracterização dos grupos funcionais foi também 
utilizada na qual a Figura 11 apresenta alguns dos espectros obtidos e a Tabela 9 apresentam as faixas características de absorção na região do infra-vermelho.

Algumas espécies de aminas e imidas que foram caracterizadas encontram-se no ANEXO 1.
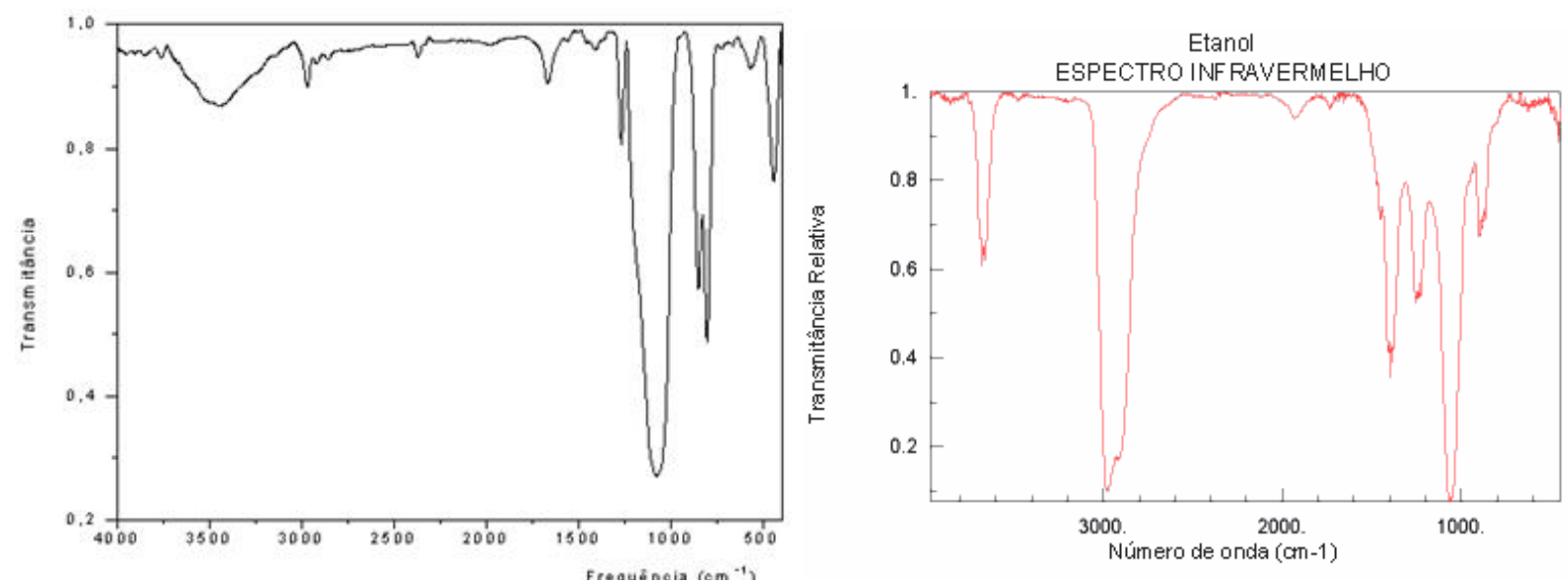

Figura 11 - Espectros de Infravermelho

Tabela 9 - Faixas características de absorção no Infra-Vermelho

\begin{tabular}{llc}
\hline Grupos Característicos & \multicolumn{1}{c}{ Vibrações } & Freqüência $\left(\mathrm{cm}^{-1}\right)$ \\
\hline Álcool & Axial O-H & $3645-3200$ \\
& Angular O-H & $1430-1200$ \\
& Axial C-O & $1210-1000$ \\
\hline Aldeído & Axial C-H & $2900-2695$ \\
& Axial C=O & $1740-1685$ \\
& Angular C-H & $1440-1325$ \\
\hline Cetona & Axial C=O & $1725-1640$ \\
& Axial e Angular C-C $(=0)-C$ & $1300-1050$ \\
\hline
\end{tabular}




\begin{tabular}{|c|c|c|}
\hline \multirow[t]{4}{*}{ Ácido Carboxílico } & Axial $\mathrm{O}-\mathrm{H}$ & $3580-2950$ \\
\hline & Axial $\mathrm{C}=\mathrm{O}$ & $1800-1680$ \\
\hline & Angular $\mathrm{O}-\mathrm{H}$ & $1440-1280$ \\
\hline & Axial C-O & $1315-1075$ \\
\hline \multirow[t]{3}{*}{ Ésteres e Lactonas } & Axial $\mathrm{C}=\mathrm{O}$ & $1795-1715$ \\
\hline & Axial $C-(C=0)-O$ & $1300-1140$ \\
\hline & Axial O-C-C & $1180-1030$ \\
\hline \multirow[t]{3}{*}{ Álcano } & Axial $\mathrm{C}-\mathrm{H}\left(\mathrm{CH}_{3}\right.$ e $\left.\mathrm{CH}_{2}\right)$ & $2985-2840$ \\
\hline & Angular $\mathrm{C}-\mathrm{H}\left(\mathrm{CH}_{3}\right.$ e $\left.\mathrm{CH}_{2}\right)$ & $1475-1440$ \\
\hline & Angular $\mathrm{C}-\mathrm{H}\left(\mathrm{CH}_{3}\right)$ & $1385-1360$ \\
\hline \multirow[t]{3}{*}{ Alceno } & Axial $\mathrm{C}-\mathrm{H}$ & $3100-3000$ \\
\hline & Axial $C=C$ & $1680-1631$ \\
\hline & Angular $\mathrm{C}-\mathrm{H}$ & $1000-650$ \\
\hline \multirow[t]{3}{*}{ Alcino } & Axial $\mathrm{C}-\mathrm{H}$ & $3350-3250$ \\
\hline & Axial $C \equiv C$ & $2260-2100$ \\
\hline & Angular $\mathrm{C}-\mathrm{H}$ & $1370-1220$ \\
\hline Éter & Axial $\mathrm{C}-\mathrm{O}-\mathrm{C}$ & $1225-1060$ \\
\hline \multirow[t]{4}{*}{ Aminas } & Axial N-H (duas absorções) & $3550-3050$ \\
\hline & Angular $\mathrm{N}-\mathrm{H}$ & $1650-1510$ \\
\hline & Axial C-N alifáticas & $1250-1020$ \\
\hline & Axial C-N aromáticas & $1360-1250$ \\
\hline Nitrilas & Axial $\mathrm{C} \equiv \mathrm{N}$ & $2260-2215$ \\
\hline \multirow[t]{5}{*}{ Amidas e Lactamas } & Axial Assimétrica $\mathrm{N}-\mathrm{H}$ & $3520-3350$ \\
\hline & Axial Simétrica $\mathrm{N}-\mathrm{H}$ & $3400-3180$ \\
\hline & Axial $\mathrm{C}=\mathrm{O}$ & $1690-1610$ \\
\hline & Angular $\mathrm{N}-\mathrm{H}$ & $1655-1510$ \\
\hline & Axial C-N & $1400-1075$ \\
\hline
\end{tabular}

A presença de substâncias nitrogenadas - aminas, indica que o resíduo é proveniente do óleo de motor. 


\section{CONCLUSÕES}

A técnica de espectrofotometria de absorção no infravermelho com transformada de Fourier, indicou a presença de várias espécies orgânicas, sendo estas: do grupo amina, poliisobutilenoamina e poliaminas de alta massa molecular, amida, isobutilenoimida e hidroxila. A presença de compostos nitrogenados, aminas e amida, são constituintes do aditivo detergente e dispersante utilizado pelos distribuidores de gasolina. A hidroxila é proveniente do álcool etílico anidro combustível misturado a gasolina.

Ambas as técnicas de espectrofotometria de emissão e a microscopia eletrônica de varredura indicaram a presença dos metais:, ferro, alumínio, cobre, zinco, sódio, potássio, cálcio e magnésio; e não metais, enxofre e silício.

A presença de metais alcalinos, sódio e potássio, caracteriza adulteração do combustível por água contaminada por estes metais.

Os metais alcalinos terrosos, cálcio e magnésio, caracterizam a presença de óleo de motor no resíduo (borra) por serem componentes da formulação do óleo com a propriedade de manter uma reserva alcalina no mesmo.

A presença dos metais, ferro, alumínio e cobre caracterizam desgaste causado por deficiência de lubrificação, bem como adulteração da gasolina pela presença elevada de álcool e água.

A presença de zinco na composição do resíduo indica a existência de óleo de motor, que é um aditivo anti-desgaste de composição organometálico, sendo este o dialquilditilfosfato de zinco.

A partir destes estudos e somados a adulteração de álcool combustível, foi desenvolvido e patenteado um aditivo com função detergente e dispersante para manter o sistema de alimentação, a câmara de combustão e válvula de admissão sem a presença de resíduo. O número da patente é PI0301679-0 fornecida pelo Instituto Nacional de Propriedade Industrial - INPI. 


\section{BIBLIOGRAFIA}

ABNT - ASSOCIAÇÃO BRASILEIRA DE NORMAS TÉCNICAS. Determinação da Massa Específica e do Teor Alcoólico do Álcool Etílico e suas Misturas com Água. Rio de Janeiro. ABNT, NBR - 5992. Jul. /1966.

AMERICAN OIL CHEMISTS SOCIETY. Official methods and recommended practices of the A.O.C.S. Champaign: A.O.C.S., 1998.

ANP, Agência Nacional do Petróleo, Gás Natural e Biocombustíveis, Regulamento Técnico no. 04/2004.

CAMPOS, A.C.; LEONTSIINIS, E.; Petróleo \& Derivados - Obtenção Especificações - Requisitos de Desempenho, Ed. Técnica Ltda: Rio de Janeiro, 1990.

CASSARET AND DOULL. Toxicology The Basic Science of Poisons; Pergamon CATALUÑA, R.; SILVA, R.; Quim. Nova, 29, 580-585, 2006.

CIENFUEGOS, F. Análise Instrumental. Rio de janeiro. Interciência, 2000.

Ensino de Química Experimental para o Segundo Grau) - Setor de Ciências Exatas, Universidade Federal do Paraná.

GUIBET, J. FAURE-BIRCHEM,E.; Fuels and Engines, ED. Technip: Paris, 1999.

HARRIS, D.C. Análise Química Quantitativa, LTC, Rio de Janeiro, 2000.

HEYWOOD,J.B.; Internal Combustion Engine Fundamentals, McGraw-Hill: New York, 1988.

http//www.anp.gov.br, acessado em 09/05/2006

http//www.br.com.br, acessado em 02/05/2006.

http//www.petrobras.com.br, acessado em 20/04/2006.

IBP. Curso de Informação sobre Combustíveis e Combustão. 10ª Edição. Rio de Janeiro. Instituto Brasileiro do Petróleo.

KELLNER, R. A. Analytical Chemistry: The Approved Text to the Fecs Curriculum Analytical, Wiley - VCH, 1998.

MALISKA, A. M. Guia de Microscopia Eletrônica de Varredura. Universidade Federal de Santa Catarina. Santa Catarina. UFSC, 2006. 
MENDHAM, J.; DENNEY, R.C.; BERNES, J.D. E THOMAS, M.J.K. - Vogel: Análise Química Quantitativa. 6ª ed. LTC: Rio de Janeiro, 2002.

Press, 4th Edition, Kansas City, Kansas - USA.

SKOOG, D.A. Princípios de Análise Instrumental. 5a. ed., Porto Alegre. Bookman, 2002.

VIDAL, Odilon. A gasolina, sua Composição e seus efeitos - Relato de uma Experiência no Ensino Médio. Curitiba, 1999. 69f. Monografia (Especialização em WAUQUIER, J. P. Petroleum Refining Crude Oil, Petroleum Products, Process Flowsheets, Editions Techinip, 1995. 


\section{ANEXO 1}

\section{Estruturas das Espécies por Infra Vermelho}

Amina-1: N,N-di-n-butil-1,3-propanodiamina<smiles>CCCCN(CCCC)CCCN</smiles>

Amina-2: 1,4-butanodiamina (Putrescina)<smiles>NCCCCN</smiles>

Amina-3: $2,2^{\prime}, 2^{\prime \prime}-$ Triaminotrietilamina (TAEA)<smiles>NCCN(CCN)CCN</smiles>

Amina-4: Diisooctilamina<smiles>CCCCC(CC)CNCC(CC)CCCC</smiles> 
Amina-5: tris-(2-hidroxipropil)amina ou triisopropanolamina<smiles>CC(O)CN(CC(C)O)CC(C)O</smiles>

Amina-6: Octadecilamina<smiles>CCCCCCCCCCCCCCCCCCN</smiles>

Amina-7: Isopropilamina

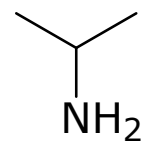

Amina-8: Isobutilamina<smiles>CC(C)CN</smiles> 
Imida-1: Ftalimida<smiles>O=C1NC(=O)c2ccccc21</smiles>

Imida-2: N-bromometil-ftalimida<smiles>O=C1c2ccccc2C(=O)N1CBr</smiles>

Imida-3: Succinimida<smiles>O=C1CCC(=O)N1</smiles>

Amida-1: Indol-3-acetamida<smiles>NC(=O)Cc1c[nH]c2ccccc12</smiles> 
Amida-2: Benzamida<smiles>NC(=O)c1ccccc1</smiles>

Amida-3: Octadecanamida<smiles>CCCCCCCCCCCCCCCCCC(N)=O</smiles>

Amida-4: Isonicotinamida<smiles>NC(=O)c1ccncc1</smiles> 
Amina-1: N,N-di-n-butil-1,3-propanodiamina 
Amina-2: 1,4-butanodiamina (Putrescina) 
Amina-3: $2,2^{\prime}, 2^{\prime \prime}-$ Triaminotrietilamina (TAEA) 
Amina-4: Diisooctilamina 
Amina-5: tris-(2-hidroxipropil)amina ou triisopropanolamina 
Amina-6: Octadecilamina 
Amina-7: Isopropilamina 
Amina-8: Isobutilamina 
Imida-1: Ftalimida 
Imida-2: N-bromometil-ftalimida 
Imida-3: Succinimida 
Amida-1: Indol-3-acetamida 
Amida-2: Benzamida 
Amida-3: Octadecanamida 
Amida-4: Isonicotinamida 